\title{
Multifunctional Gold Nanocarriers for Cancer Theranostics - From Bench to Bedside and Back Again?
}

Joao Conde

Universidad de Zaragoza, Spain

Furong Tian

Technological University Dublin, furong.tian@tudublin.ie

Pedro V. Baptista

CIGMH, Departamento de Ciências da Vida, Faculdade de Ciências e Tecnologia, Universidade Nova de Lisboa, Campus de Caparica, 2829-516 Caparica, Portugal

See next page for additional authors

Follow this and additional works at: https://arrow.tudublin.ie/nanolbk

Part of the Medical Sciences Commons

\section{Recommended Citation}

Conde, J. et al. (2014) Book chapter (11) taken from Nano-oncologicals: new targeting and delivery approaches, published by Springer 2014, ISBN- 978-3319080833.

This Book Chapter is brought to you for free and open access by the NanoLab at ARROW@TU Dublin. It has been accepted for inclusion in Books / book chapters by an authorized administrator of ARROW@TU Dublin. For more information, please contact arrow.admin@tudublin.ie, aisling.coyne@tudublin.ie, gerard.connolly@tudublin.ie. 


\section{Authors}

Joao Conde, Furong Tian, Pedro V. Baptista, and Jesús M. de la Fuente 


\title{
Multifunctional Gold Nanocarriers for Cancer Theranostics - From
}

\section{bench to bedside and back again?}

João Conde ${ }^{a, b, *}$, Furong Tian ${ }^{c}$, Pedro V. Baptista ${ }^{b}$, Jesús M. de la Fuente ${ }^{a}$

${ }^{a}$ Instituto de Nanociencia de Aragon (INA), Universidad de Zaragoza, Zaragoza, 50018, Spain.

${ }^{\text {b }}$ CIGMH, Departamento de Ciências da Vida, Faculdade de Ciências e Tecnologia, Universidade Nova de Lisboa, Campus de Caparica, 2829-516 Caparica, Portugal.

${ }^{c}$ Comprehensive Pneumology Centre, Institute of Lung Biology and Disease, Helmholtz Zentrum München, Neuherberg, Germany.

[*] Corresponding-Author

\begin{abstract}
After a quarter of century of rapid technological advances, research has revealed the complexity of cancer, a disease intimately related to the dynamic transformation of the genome. However, the full understanding of the molecular onset of this disease is still far from achieved and the search for mechanisms of treatment will follow closely.

It is here that Nanotechnology enters the fray offering a wealth of tools to diagnose and treat cancer. It is indisputable that the use of gold nanocarriers has been gaining momentum as vectors for therapy and diagnostic strategies, combining the AuNPs' ease of functionalization with numerous biomolecules, high loading capacity and fast uptake by target cells. In fact, over the last decade nearly 12.000 research papers focusing on multifunctional gold nanocarriers have been published in peer-reviewed journals. Some of the described nanosystems will most likely revolutionize our understanding of biological mechanisms and push forward the clinical practice through their
\end{abstract}


integration in future diagnostics platforms. Nevertheless, very little gave fruitful results in order to improve a bench-to-bedside approach to translational research. On the basis of theoretical and experimental results obtained so far are we or not at the point: from bench to bedside and back again? As you will see, the answers to this question are complex, but one thing is clear: Translation into clinics is a tortuous and difficult path. Here, we provide a critical review about the available multifunctional gold nanocarriers for in vitro application and in vivo cancer targeting on nanodiagnostics and therapy.

Keywords: cancer; gold nanoparticles; nanomedicine; theranostics; nanotoxicity.

\section{Introduction}

The National Cancer Institute predicts that over the next years, nanotechnology will result in important advances in early detection, molecular imaging, targeted and multifunctional therapeutics, prevention and control of cancer (2010). Nanotechnology offers numerous tools to diagnose and treat cancer, such as new imaging agents, multifunctional devices capable of overcome biological barriers to deliver therapeutic agents directly to cells and tissues involved in cancer growth and metastasis, and devices capable of predicting molecular changes to prevent action against precancerous cells (Baptista, 2009).

Nanoparticle-based delivery systems in Theranostics (Diagnostics \& Therapy) provide better penetration of therapeutic and diagnostic substances within the body at a reduced risk in comparison to conventional therapies (Ma et al., 2011;Praetorius and Mandal, 2007). Limitations in medical practice are intimately associated with the fact that diagnostics, therapy and therapy guidance are mostly separate from each other. It is here that theranostics unites the three stages in one single process, supporting early-stage diagnosis and treatment, overcoming some of the sensitivity and specificity of current medicines (Lammers et al., 2010;Pene et al., 2009;Lammers et al., 2011). At 
the present time, there is a growing need to enhance the capability of theranostics procedures where nanoparticle-based sensors may provide for the simultaneous detection of several gene-associated conditions and nanodevices with the ability to monitor real-time drug action. These innovative multifunctional nanocarriers for cancer theranostics may allow the development of diagnostics systems such as colorimetric and immunoassays, and in therapy approaches through gene therapy, drug delivery and tumor targeting systems (Figure 1).

Nowadays the main challenge is to develop a system for molecular therapy capable of circulating in the blood stream undetected by the immune system and capable to recognize the desirable target and signal it for effective drug delivery or gene silencing. As a result, nanotechnology is playing a role in providing new types of nanotherapeutics for cancer that have the potential to provide effective therapies with minimal side effects and with high specificity (Heath and Davis, 2008). The interdisciplinary and vibrant field of nanotechnology continues giving us hope of a personalized medicine as a part of cancer patient management. Gold nanoparticles (AuNPs) are one of those nanosystems that provide non-toxic carriers for drug and gene delivery applications (Nishiyama, 2007;Ghosh et al., 2008a). They are versatile agents with a variety of biomedical applications including use in highly sensitive diagnostic assays (Goodman et al., 2004), thermal ablation and radiotherapy enhancement (Hirsch et al., 2003;Hainfeld et al., 2004;Hainfeld et al., 2008), as well as drug and gene delivery (Hong et al., 2006; Thomas and Klibanov, 2003a).

The unique characteristics of AuNPs in the nanometer range, such as high surface-to-volume ratio or size-dependent optical properties, are drastically different from those of their bulk materials and hold pledge in the clinical field for disease therapeutics (Kim, 2007;Heath and Davis, 2008).

Nanoparticles (NPs) exhibiting these unique and broad-based optical properties, ease of synthesis and facile surface chemistry and functionalization, and appropriate size scale are generating much eagerness in clinical diagnostics and therapy. The most common applications in which gold 
nanocarriers have been used so far are labeling, delivering, heating, sensing and detection (Sperling et al., 2008).

In spite of these advantages, nanoparticles show some limitations, such as their small size and large surface area can lead to particle-particle aggregation and may result in limited loading of functional components and burst release. In fact, only NPs with the appropriate size (and surface chemistry) will not be immediately recognized by our immune system and committed to removal from the organism, thus showing increased circulation times. Also, size and surface properties play an important role to avoid clearance (Sperling and Parak, 2010). For example, hydrophilic nanoparticles with an effective size in the range of 10 to $100 \mathrm{~nm}$ are small enough to slow down activation of the mononuclear phagocyte system and are big enough to avoid renal filtration (Gil and Parak, 2008). Nanoparticles with unique and broad-based optical properties, ease of synthesis and facile surface chemistry and functionalization, and appropriate size scale are generating much eagerness in biotechnology and biomedicine with particular emphasis in clinical diagnostics and therapy (Doria et al., 2012). However for the biological application of these multifunctional NPs, is necessary their functionalization with one or several biomolecules such as DNA/RNA, oligonucleotides (i.e. ssDNA/RNA, dsDNA/RNA ), peptides and antibodies, fluorescent dyes, polymers, drugs, tumoral markers, enzymes and other proteins that will introduce several functionalities and moieties. In the end the conjugation strategy is directly dependent of a numbers of factors, namely the NPs size, surface chemistry and shape, as well as the type of ligands and functional groups one desires to exploit in the functionalization (Sperling and Parak, 2010).

When referring to cancer therapy, targeting and localized delivery are of utmost importance to enhance the therapeutic effect and decrease an adverse distribution to healthy organs and tissues. Multifunctional gold nanocarriers may potentiate the development of individualized cancer therapy based on the individual's biological information within the tumor (i.e. biomolecular profiling). Gold 
nanocarriers can be modified with multiple cell-targeting and membrane translocating peptides, loaded with DNA/RNA and used as nanovectors (Gil and Parak, 2008;Peer et al., 2007).

In this chapter, we will focus on the exciting new methods and applications of AuNPs for cancer diagnosis and therapy with particular emphasis on their use in vivo and their potential to be translated into clinical settings.

\section{Nanodiagnostics}

Nanodiagnostics can be defined as the use of nano-sized materials, devices or systems for diagnostics purposes (Doria et al., 2007a). It is a promising field as more and improved techniques are becoming available for clinical diagnostics with increased sensitivity at lower costs (Baptista et al., 2008;Baptista et al., 2005;Doria et al., 2007b;Baptista et al., 2006).

The use of the colloidal gold color change upon aggregation is the best characterized example for diagnostic systems using AuNPs. In fact, AuNPs functionalized with ssDNA capable of specifically hybridizing to a complementary target for the detection of specific nucleic acid sequences in biological samples have been extensively used (Li and Rothberg, 2004;Mirkin et al., 1996; Thaxton et al., 2006;Cheng et al., 2006;Baptista et al., 2008;Doria et al., 2007b;Taton et al., 2000; Qin and Yung, 2007; Sato et al., 2005;Sato et al., 2003;Elghanian et al., 1997).

The use of thiol-linked ssDNA-modified gold nanoparticles for the colorimetric detection of gene targets represents an inexpensive and easy to perform alternative to fluorescence or radioactivitybased assays (Storhoff et al., 2004). In 1996, Mirkin et al. (Mirkin et al., 1996) described the use of a cross-linking method that relies on the detection of single-stranded oligonucleotide targets using two different Au-nanoprobes, each of them functionalized with a DNA-oligonucleotide complementary to one half of the given target. A mixture of gold nanoparticles with surface-immobilized noncomplementary DNA sequences appears red in color and has a strong absorbance at $520 \mathrm{~nm}$. When a complementary DNA sequence is added, the nanoparticles are reversibly aggregated causing a red 
shift in the surface plasmon absorbance to $574 \mathrm{~nm}$, and the solution becomes purple in color. Consequently, these AuNPs reversibly assemble by the formation of the DNA duplex, linking the particles together. These pioneer work gave the research community the idea of an easy method to sensitized oligonucleotide-AuNP conjugates, with intense and highly tunable optical properties, ease of conjugation though the gold-thiol bond, catalytic properties, and relative biocompatibility (Thaxton et al., 2006; Cao et al., 2005).

On the other hand, in 2005 Baptista et al. introduced a non-cross linking method where thiol-linked DNA-gold nanoparticles were used in a novel colorimetric method to detect the presence of specific mRNA from a total RNA extract of yeast cells (Baptista et al., 2005). The method consists in visual and/or spectrophotometric comparison of solutions before and after salt induced Au-nanoprobe aggregation (see Figure 2) - the presence of a complementary target prevents aggregation and the solution remains red and has a strong absorbance at $\pm 520 \mathrm{~nm}$; non-complementary/mismatched targets do not prevent Au-nanoprobe aggregation, resulting in a visible change of color from red to blue and therefore a shift in the surface plasmon absorbance to $600-650 \mathrm{~nm}$. This method has been successfully applied to detect eukaryotic gene expression without retro-transcription or PCR amplification steps (Conde et al., 2010b;Baptista et al., 2005); to distinguish fully complementary from mismatched sequences, with a single base mismatch i.e. to detect common mutations within the $\beta$-globin gene (Doria et al., 2007b); and in a fast and straightforward assay for Mycobacterium tuberculosis DNA detection in clinical samples (Costa et al., 2009;Baptista et al., 2006). Other approaches are the use of AuNPs as a core/seed that can be tailored with a wide variety of surface functionalities to provide highly selective nanoprobes for diagnosis (You et al., 2007); the utilization of Surface Plasmon resonance (SPR) scattering imaging or SPR absorption spectroscopy generated from antibody conjugated AuNPs in molecular biosensor techniques for the diagnosis and investigation of oral epithelial living cancer cells in vivo and in vitro (El-Sayed et al., 2005a); the use of multifunctional AuNPs which incorporate both cytosolic delivery and targeting moieties on the 
same particle functioning as intracellular sensors to monitoring actin rearrangement in live fibroblasts (Kumar et al., 2007); and the employment of AuNPs in electrochemical based methods that can be coupled with metal deposition for signal enhancement (Castaneda et al., 2007). Gold NPs have already proven to be one of the most important groups of nanomaterials for biosensing approaches. Highly sensitive and specific biosensors based on AuNPs have open up the possibility of creating new diagnostic platforms for disease markers, biological and infectious agents in the early-stage detection of disease and threats, especially in cancer (Conde et al., 2012b;Doria et al., 2012).

\subsection{Gold nanocarriers in Cancer Diagnosis}

Cancer is the one of first leading causes of mortality in the modern world, with more than 10 million new cases every year (Hanahan and Weinberg, 2000; Siegel et al., 2012). Some continue to argue that the search for the origin and treatment of this disease will continue through the next quarter of century, adding successive layers of complexity to an investigation that per se is very complex. In fact, advances in diagnosis and treating this disease that kills millions of people each year worldwide, have not been as effective as for other chronic diseases, and only for some types of cancer there are effective methods of detection (Hanahan and Weinberg, 2000). The high mortality rate in cancer is commonly attributed to the difficulties in detecting the disease at an early treatable stage. The main challenge is to find new and more effective diagnostic agents for the monitorization of predictive cell molecular changes that are involved in tumor development as the key to the efficient and ultimately triumphant treatment of cancer is early and accurate diagnosis (Etzioni et al., 2003).

It is here that nanotechnology enters the fight in the technological leap of controlling materials at nanoscale by offering a "big revolution" in new medical and healthcare diagnostic systems (Gil and Parak, 2008). In fact, nanotechnology combined with biology and medicine is the most advanced 
technology both from an academic point-of-view and for commercial applications, producing major advances in molecular diagnostics and bioengineering (Giljohann et al., 2010;Salata, 2004). AuNPs are one of those nanosystems that provide non-toxic carriers with a variety of biomedical applications including use in highly sensitive diagnostic assays (Conde et al., 2012b;Doria et al., 2012).

In reality the multiplexed marker protein assays are critical in the diagnosis of complex diseases like cancer. In fact, AuNP probes barcoded with reporter DNAs and a capture antibody have been extensively used with great promise (Stoeva et al., 2006;Son and Lee, 2007). For instance, AuNP imunoassays are one of the most used nanosystems in cancer detection. Mirkin and co-workers developed an ultrasensitive method for detecting protein analytes. This facile immunoassay was used for the detection of prostate specific antigen (PSA, a valuable biomarker for prostate cancer screening) and had an almost one million-fold higher sensitivity than a conventional ELISA-based assay (Nam et al., 2003). This study was the first step to use six years later the AuNP bio-barcode assay probe for the detection of PSA in a clinical pilot study with 18 men who have undergone radical prostatectomy for prostate cancer. This new bio-barcode PSA assay is approximately 300 times more sensitive than commercial immunoassays (Thaxton et al., 2009).

Also, Huang et al. have reported a PSA immunoassay on a commercially available surface plasmon resonance biosensor. This sandwich assay with AuNPs was used for a major enhancement in sensitivity of PSA detection at clinical relevant concentrations (Huang et al., 2005). Other study demonstrated a highly sensitive organic electrochemical transistor based immunosensor with secondary antibody-conjugated AuNPs with a low detection limit for PSA. These sensor performances were particularly improved in the lower concentration range where the detection is clinically important for the preoperative diagnosis and screening of prostate cancer (Huang et al., 2005). 
Additionally, AuNP probes coupled with dynamic light scattering (DLS) measurements can also be used for the development of a one-step homogeneous immunoassay for the detection of free-PSA. The light scattering intensity of nanoparticles and nanoparticle oligomers is several orders of magnitude higher than proteins, making it possible to detect nanoparticle probes in the low picomolar concentration range (Liu et al., 2008).

AuNPs scatter light intensely at or near their surface plasmon wavelength region and when coupled with DLS detection can be very useful for serum protein biomarker detection and analysis. Huo et al. reported the use of citrate-AuNP to absorb proteins from the serum and form a protein corona on the nanoparticle surface. The protein corona formation and the subsequent binding of antibody to the target proteins in the protein corona were detected by DLS. Using this simple assay, the authors discovered multiple molecular aberrations associated with prostate cancer from both mice and human blood serum samples (Huo et al., 2012;Huo et al., 2011).

Other authors have taken a different approach to addressing the use of AuNPs in cancer biomarker detection by employing the biological applications of antibody-conjugated AuNPs in several types of cancer, such as breast cancer (Ambrosi et al., 2010;Lu et al., 2010a), pancreatic adenocarcinoma (Eck et al., 2008), cervical cancer (Rahman et al., 2005), epithelial cancer (Yang et al., 2008), liver cancer (Lan et al., 2011), prostate cancer (Lukianova-Hleb et al., 2011) and oral cancer (El-Sayed et al., 2005a).

The mechanism of selectivity and all these immunoassay's response open up a new possibility of rapid, simple, clean, easy, economically very cheap, non-toxic and reliable diagnosis of cancer. In fact, antibody-conjugated AuNPs are one of the most used nanosystems in cancer diagnostics, being useful in molecular biosensor techniques for the diagnosis and investigation of cancer cells in vivo and in vitro. The importance of these nanosystems can be demonstrated by a significant number of companies involved in the synthesis and applications of antibody-conjugated nanoparticles, such as 
Magnisense SAS, Diagnostic Biosensors, LLC, Alnis Biosciences Inc. and Invitrogen Corp (Arruebo et al., 2009).

Direct detection of cancer cells using colorimetric assays with AuNPs has been extensively used due to their simplicity and versatility, among which those based on LSPR. LSPR is the collective oscillation of the electrons in the conduction band, which is usually in the visible region giving rise to the strong surface plasmon resonance absorption (Daniel and Astruc, 2004). These AuNPs are commonly functionalized with biomolecules (e.g., DNA, RNA, peptides, enzymes) and capable of recognizing molecular events associated with cancer development down to femtomolar level with single base discrimination resolution (Kang et al., 2010;Li et al., 2005;Medley et al., 2008). Molecular nanodiagnostics applied to cancer may provide rapid and sensitive detection of cancer related molecular alterations, which would enable early detection even when those alterations occur only in a small percentage of cells. For instance, Conde et al. present an AuNPs based approach for the molecular recognition and quantification of the $B C R-A B L$ fusion transcript, which is responsible for chronic myeloid leukemia (CML). This inexpensive and very easy to perform method allows quantification of unamplified total human RNA and specific detection of the oncogene transcript. This assay may constitute a promising tool in early diagnosis of CML and could easily be extended to further target genes with proven involvement in cancer development (Conde et al., 2010b;Conde et al., 2012c). The sensitivity settled by the Au-nanoprobes allows differential gene expression from $10 \mathrm{ng} / \mu \mathrm{l}$ of total RNA and takes less than 30 minutes to complete after total RNA extraction, minimizing RNA degradation (see Figure 2).

Also, aptamer-conjugated AuNPs have become a powerful tool for point of care diagnostics (Mukerjee et al., 2012). Most of the common aptamer-AuNP assays are able to differentiate between different types of target and control cells based on the aptamer used in the assay, indicating the wide applicability for cancer cell detection. For instance, Liu et al. reported the use of an aptamernanoparticle strip biosensor for the rapid, specific, sensitive, and low-cost detection of circulating 
cancer cells in human blood, showing great promise for in-field and point-of-care cancer diagnosis and therapy (Liu et al., 2009). In another study, Medley et al. have developed a colorimetric assay for the direct detection of diseased cells and thus capable of distinguish between cancer cells and noncancerous cells. This assay combines the selectivity and affinity of aptamers and the spectroscopic advantages of AuNPs to allow for the sensitive detection of cancer cells with both the naked eye and based on absorbance measurements (Medley et al., 2008). Another important aspect correlated with disease state in cancer patients is the presence of circulating tumor cells in the bloodstream. In order to induce optical contrast in non-pigmented cancer cells, Viator et al. attached AuNPs to a prostate cancer cell line, using optical absorption to detect such cells in a photoacoustic flowmeter designed to find circulating tumor cells in blood samples (Viator et al., 2010). Another application of AuNPs in cancer is their capability to target and provide in vivo tumor detection using Surface-enhanced Raman scattering - SERS. SERS has led the way in terms of use of spectroscopic methods for signal enhancement by nanostructured metal surfaces towards in vivo tracking of biomolecules trafficking (Stiles et al., 2008;Wilson and Willets, 2013). SERS has been extensively used for molecular/ion detection and bioimaging applications since it minimizes photoblinking or photobleaching from conventional fluorophores, decreases signal-to-noise ratio in complex in vitro and in vivo, and usually Raman reporters are stable and yield large optical enhancements (Alvarez-Puebla and Liz-Marzan, 2010;Samanta et al., 2011;Alvarez-Puebla and LizMarzan, 2012b;Alvarez-Puebla and Liz-Marzan, 2012a). AuNPs covered by Raman reporters have been used for SERS to detect cancer cells in vitro and tumours in vivo (Kong et al., 2012; Qian et al., 2008b). Actually, Lin et al. described the tremendous potential of using AuNP based-SERS to obtain blood serum biochemical information for non-invasive colorectal cancer detection (Lin et al., 2011). Raman reporters when combined with AuNPs can elicit an optical contrast to discriminate between cancerous and normal cells and their conjugation with antibodies allowed them to map the expression of relevant biomarkers for molecular imaging (Kah et al., 2007), ], as well as detect and 
characterized circulating tumor cells. These SERS nanoparticles constitute an important tool for clinical research once they can successfully identified circulating tumor cells in the peripheral blood of 19 patients with squamous cell carcinoma of the head and neck (Wang et al., 2011).

The papers discussed earlier report the development of nanoscale devices and platforms that can be used for improved biomarker detection, such as nucleic acids (DNA or RNA) or proteins. However, the development of molecular diagnosis of cancer and at the same time the selective delivery of a specific anticancer agent by joining diagnostics and therapy (theranostics) on a single nanodevice will most definitely revolutionizing the way we manage cancer (Baptista, 2012).

Table 1 summarizes the latest types of AuNP-based biosensors for cancer dignostics, according to their methodology principle. Some of the described nanosystems will most likely revolutionize our understanding of biological mechanisms and push forward the clinical practice through their integration in future diagnostics platforms. Nevertheless, very little gave successful results or went to clinical trials. Therefore new synthesis, fabrication, and characterization methods are needed for developing highly advanced AuNPs capable of use in sensitive and multiple detection methods with negligible toxicity and high sensitivity. In the future, it might be possible to apply all AuNPs properties together and evolve new chemistry for synthesis of smart materials for diagnostic applications and clinical trials.

Table 1. Summary of the latest AuNP-based biosensors used in cancer diagnostics according to the type of NP, surface modification, type of cancer and explored methodology principle.

\begin{tabular}{|c|c|c|c|c|c|}
\hline Method & $\begin{array}{l}\text { Type } \\
\text { of NP }\end{array}$ & $\begin{array}{c}\text { Surface } \\
\text { modification }\end{array}$ & $\begin{array}{c}\text { Target/Cells/ } \\
\text { Samples }\end{array}$ & $\begin{array}{l}\text { Type of } \\
\text { Cancer }\end{array}$ & $\begin{array}{c}\text { Comments } \\
\text { [Reference] }\end{array}$ \\
\hline \multirow[t]{2}{*}{$\begin{array}{l}\text { Colorimetric } \\
\text { Scanometric }\end{array}$} & $\begin{array}{c}40 \mathrm{~nm} \\
\text { spherical }\end{array}$ & $\begin{array}{l}\text { dA-tailed probe } \\
\text { applied to the strip, } \\
\text { which contains } \\
\text { oligo(dT)- } \\
\text { conjugated AuNPs } \\
\text { in dry form }\end{array}$ & $\begin{array}{l}\text { Fusion genes in } \\
\text { K562 cell line }\end{array}$ & $\begin{array}{l}\text { acute and } \\
\text { chronic } \\
\text { leukemia }\end{array}$ & $\begin{array}{l}\text { Dry-reagent, disposable, } \\
\text { dipstick test for molecular } \\
\text { screening of seven } \\
\text { chromosomal translocations } \\
\text { associated with acute and } \\
\text { chronic leukemia } \\
\text { (Kalogianni et al., 2007) }\end{array}$ \\
\hline & $\begin{array}{c}13 \mathrm{~nm} \\
\text { spherical }\end{array}$ & ssDNA & $\begin{array}{l}\text { BCR-ABL b3a2 } \\
\text { (e14a2) fusion }\end{array}$ & $\begin{array}{l}\text { Chronic } \\
\text { myeloid }\end{array}$ & $\begin{array}{c}\text { Detection and quantification } \\
\text { of the }\end{array}$ \\
\hline
\end{tabular}




\begin{tabular}{|c|c|c|c|c|c|}
\hline & & & transcript & leukemia & $\begin{array}{l}\text { BCR-ABL gene fusion using } \\
\text { thiol-DNA modified AuNPs } \\
\text { (Conde et al., 2010b) }\end{array}$ \\
\hline & $\begin{array}{c}30 \mathrm{~nm} \\
\text { spherical }\end{array}$ & $\begin{array}{l}\text { thiol-terminated } \\
\text { DNA barcodes; } \\
\text { anti-PSA antibodies }\end{array}$ & $\begin{array}{l}\text { Prostate-specific } \\
\text { antigen PSA } \\
\text { (biomarker for } \\
\text { prostate cancer } \\
\text { screening) }\end{array}$ & Prostate cancer & $\begin{array}{l}\text { Nanoparticle based bio- } \\
\text { barcode for PSA detection } \\
\text { (Thaxton et al., 2009) }\end{array}$ \\
\hline & $\begin{array}{l}15 \mathrm{~nm} \\
\text { spherical }\end{array}$ & $\begin{array}{l}\text { antibody anti- } \\
\text { CA15-3-HRP } \\
\text { (horseradish } \\
\text { peroxidase) }\end{array}$ & $\begin{array}{l}\text { CA15-3 breast } \\
\text { cancer biomarker } \\
\text { in human serum }\end{array}$ & Breast cancer & $\begin{array}{l}\text { Enhanced AuNP based } \\
\text { ELISA for a breast cancer } \\
\text { biomarker detection } \\
\text { (Ambrosi et al., 2010) }\end{array}$ \\
\hline & $\begin{array}{l}\text { oval- } \\
\text { shaped }\end{array}$ & $\begin{array}{l}\text { monoclonal anti- } \\
\text { HER2/c-erb-2 } \\
\text { antibody; S6 RNA } \\
\text { aptamer-conjugated }\end{array}$ & SK-BR-3 cells & Breast cancer & $\begin{array}{l}\text { Colorimetric and highly } \\
\text { sensitive two-photon } \\
\text { scattering assay for highly } \\
\text { selective and sensitive } \\
\text { detection of breast cancer } \\
\text { (Lu et al., 2010a) }\end{array}$ \\
\hline \multirow{6}{*}{ Immunoassays } & $\begin{array}{c}15 \mathrm{~nm} \\
\text { spherical }\end{array}$ & $\begin{array}{l}\text { dithiol-PEG- } \\
\text { COOH; F19 } \\
\text { monoclonal } \\
\text { antibodies }\end{array}$ & $\begin{array}{l}\text { Tissues from } \\
\text { cancerous and } \\
\text { healthy human } \\
\text { pancreas (patients } \\
\text { undergoing } \\
\text { pancreatic } \\
\text { resection) } \\
\end{array}$ & $\begin{array}{c}\text { Pancreatic } \\
\text { adenocarcinoma }\end{array}$ & $\begin{array}{l}\text { pancreatic adenocarcinoma } \\
\quad(\text { Eck et al., 2008) }\end{array}$ \\
\hline & $\begin{array}{c}25 \mathrm{~nm} \\
\text { spherical }\end{array}$ & $\begin{array}{l}\text { anti-EGFR and } \\
\text { non-specific IgG } \\
\text { antibodies }\end{array}$ & $\begin{array}{l}\text { SiHa cervical } \\
\text { cancer cells }\end{array}$ & Cervical cancer & $\begin{array}{l}\text { Optical imaging of cervical } \\
\text { pre-cancers using AuNPs } \\
\text { and CdSe QDs for } \\
\text { reflectance and fluorescence } \\
\text { imaging (Rahman et al., } \\
\text { 2005) }\end{array}$ \\
\hline & $\begin{array}{c}10 \mathrm{~nm} \\
\text { spherical }\end{array}$ & $\begin{array}{c}\text { antibody } \\
\text { (Cetuximab) }\end{array}$ & $\begin{array}{l}\text { epidermal growth } \\
\text { factor receptor } \\
\text { (EGFR) in A431 } \\
\text { cells }\end{array}$ & Liver cancer & $\begin{array}{l}\text { High-performance probes } \\
\text { based on AuNPs for } \\
\text { detection of live cancer cell } \\
\text { (Yang et al., 2008) }\end{array}$ \\
\hline & $\begin{array}{c}16 \mathrm{~nm} \\
\text { spherical }\end{array}$ & $\begin{array}{l}\text { NHS-PEG; mouse } \\
\text { anti-human AFP } \\
\text { antibodies } \\
\text { (antibody-1 and } \\
\text { antibody-2) } \\
\end{array}$ & $\begin{array}{l}\text { liver cancer } \\
\text { biomarker alpha- } \\
\text { fetoprotein (AFP) }\end{array}$ & Liver cancer & $\begin{array}{c}\text { One-step homogeneous } \\
\text { detection of cancer marker } \\
\text { using antibody-AuNP probes } \\
\text { (Lan et al., 2011) }\end{array}$ \\
\hline & $\begin{array}{c}60 \mathrm{~nm} \\
\text { spherical }\end{array}$ & $\begin{array}{l}\text { PSMA (prostate } \\
\text { specific membrane } \\
\text { antigen); C225 } \\
\text { (Erbitux, the } \\
\text { antibody raised } \\
\text { against human EGF } \\
\text { receptor) } \\
\end{array}$ & $\begin{array}{l}\text { living bone } \\
\text { metastatic prostate } \\
\text { cancer }(\mathrm{C} 4-2 \mathrm{~B}) \\
\text { human bone } \\
\text { marrow stromal } \\
\text { (HS-5) cells }\end{array}$ & Prostate cancer & $\begin{array}{l}\text { Tunable plasmonic } \\
\text { nanoprobes for theranostics } \\
\text { of prostate Cancer } \\
\text { (Lukianova-Hleb et al., } \\
\text { 2011) }\end{array}$ \\
\hline & $\begin{array}{c}35 \mathrm{~nm} \\
\text { spherical }\end{array}$ & $\begin{array}{l}\text { monoclonal anti- } \\
\text { epidermal growth } \\
\text { factor receptor } \\
\text { (anti-EGFR) }\end{array}$ & $\begin{array}{l}\text { nonmalignant } \\
\text { epithelial cells } \\
\text { (HaCaT); } \\
\text { malignant oral } \\
\text { epithelial cells } \\
\text { (HOC } 313 \text { clone } 8 \\
\text { and HSC } 3 \text { ) }\end{array}$ & Oral cancer & $\begin{array}{c}\text { Surface plasmon resonance } \\
\text { scattering and absorption of } \\
\text { antibody-AuNPs in oral } \\
\text { cancer diagnostics (El-Sayed } \\
\text { et al., 2005a) }\end{array}$ \\
\hline \multirow{2}{*}{$\begin{array}{l}\text { Surface- } \\
\text { enhanced } \\
\text { Raman } \\
\text { scattering - } \\
\text { SERS }\end{array}$} & $\begin{array}{c}30 \mathrm{~nm} \\
\text { spherical }\end{array}$ & $\begin{array}{l}\text { mouse anti-human } \\
\text { free PSA clone } \\
\text { PSA-F65 and clone } \\
\text { PSA-66 }\end{array}$ & $\begin{array}{l}\text { Prostate-specific } \\
\text { antigen (PSA) in } \\
\text { human serum }\end{array}$ & Prostate cancer & $\begin{array}{l}\text { Detection of PSA with an } \\
\text { immunoassay based on } \\
\text { SERS and immunogold } \\
\text { labels (Grubisha et al., 2003) }\end{array}$ \\
\hline & $\begin{array}{c}43 \mathrm{~nm} \\
\text { spherical }\end{array}$ & human serum & human serum & $\begin{array}{l}\text { Colorectal } \\
\text { cancer }\end{array}$ & $\begin{array}{l}\text { AuNP based-SERS to obtain } \\
\text { blood serum biochemical }\end{array}$ \\
\hline
\end{tabular}




\begin{tabular}{|c|c|c|c|c|c|}
\hline & & & & & $\begin{array}{l}\text { information for non-invasive } \\
\text { colorectal cancer detection } \\
\text { (Lin et al., 2011) }\end{array}$ \\
\hline & $\begin{array}{c}60 \mathrm{~nm} \\
\text { spherical }\end{array}$ & $\begin{array}{l}\text { QSY reporter } \\
\text { molecules; thiol- } \\
\text { PEG-COOH; } \\
\text { epidermal growth } \\
\text { factor (EGF) } \\
\text { peptide }\end{array}$ & $\begin{array}{l}\text { epidermal growth } \\
\text { factor (EGF) }\end{array}$ & $\begin{array}{l}\text { Squamous cell } \\
\text { carcinoma of } \\
\text { the head and } \\
\text { neck }\end{array}$ & $\begin{array}{l}\text { SERS AuNPs identified } \\
\text { circulating tumor cells in the } \\
\text { peripheral blood of cancer } \\
\text { patients (Wang et al., 2011). }\end{array}$ \\
\hline & $\begin{array}{l}35-50 \mathrm{~nm} \\
\text { spherical }\end{array}$ & $\begin{array}{c}\text { Thiol-DNA hairpin } \\
\text { tagged with a } \\
\text { Raman label }\end{array}$ & BRCA1 SNPs & Breast cancer & $\begin{array}{c}\text { Plasmonic } \\
\text { nanoprobes for detection of } \\
\text { SNPs in breast cancer } \\
\text { BRCA1 gene (Wabuyele et } \\
\text { al., 2010) }\end{array}$ \\
\hline \multirow{3}{*}{ Electrochemical } & $\begin{array}{c}5 \mathrm{~nm} \\
\text { spherical }\end{array}$ & $\begin{array}{l}\text { Glutathione (GSH); } \\
\text { primary antibodies } \\
\text { for human } \\
\text { Interleukin-8 }\end{array}$ & $\begin{array}{l}\text { Interleukin-8 (IL-8) } \\
\text { cancer biomarker } \\
\text { in human serum }\end{array}$ & $\begin{array}{c}\text { Cancer } \\
\text { biomarker }\end{array}$ & $\begin{array}{c}\text { Ultrasensitive } \\
\text { immunosensor based on a } \\
\text { glutathione-protected } \\
\text { AuNP sensor surface } \\
\text { (Munge et al., 2011) }\end{array}$ \\
\hline & $\begin{array}{c}4 \mathrm{~nm} \\
\text { spherical }\end{array}$ & $\begin{array}{c}\text { antibodies for IL-6; } \\
\text { biotinylated } \\
\text { secondary antibody } \\
\text { with } 16-18 \\
\text { horseradish } \\
\text { peroxidase labels } \\
\end{array}$ & $\begin{array}{l}\text { Interleukin-6 (IL-6) } \\
\text { cancer biomarker } \\
\text { in calf serum }\end{array}$ & $\begin{array}{c}\text { Cancer } \\
\text { biomarker }\end{array}$ & $\begin{array}{c}\text { Inkjet printed AuNP } \\
\text { electrochemical arrays for } \\
\text { immunodetection of a cancer } \\
\text { biomarker protein (Jensen et } \\
\text { al., 2011) }\end{array}$ \\
\hline & $\begin{array}{c}13 \mathrm{~nm} \\
\text { spherical }\end{array}$ & $\begin{array}{c}\text { Alkaline } \\
\text { phosphatase; poly } \\
\text { (styrene-co-acrylic } \\
\text { acid); TNF- } \alpha \\
\text { antibody }\end{array}$ & $\begin{array}{l}\text { Tumor necrosis } \\
\text { factor } \alpha(\mathrm{TNF}-\alpha) \text { in } \\
\text { human serum }\end{array}$ & $\begin{array}{c}\text { Tumor necrosis } \\
\text { factor }\end{array}$ & $\begin{array}{l}\text { Electrochemical } \\
\text { immunosensor of tumor } \\
\text { necrosis factor based on } \\
\text { alkaline phosphatase } \\
\text { functionalized NPs (Yin et } \\
\text { al., 2011) }\end{array}$ \\
\hline
\end{tabular}

\section{Nanotherapy}

In medical terms, a therapeutic effect is a consequence of a medical treatment of any kind, the results of which are judged to be desirable and beneficial. Conventional therapy methods in cancer involve the employment of anticancer agents that do not greatly differentiate between cancerous and normal cells (Minelli et al., 2010). Efficient in vivo targeting to heterogeneous population of cancer cells and tissue still requires better selectivity and decreased toxicity to surrounding normal cells, towards a decrease of systemic toxicity, adverse and severe side effects (Liu et al., 2007).

In another way, universally targeting cells within a tumor is not always feasible because some drugs cannot diffuse efficiently and the random nature of the approach makes it difficult to control the process and may induce multiple-drug resistance (MDR) - a situation where chemotherapy 
treatments fail patients owing to resistance of cancer cells towards one or more drugs (Peer et al., 2007). Consequently, nanotechnology could offer a less invasive alternative, enhancing the life expectancy and quality of life of the patient (Cuenca et al., 2006).

At the moment, it is expected that the greatest gains in therapeutic selectivity will be achieved by synergistic combinations of several multicomponent targeting strategies. Currently, it is essential to develop technology for target and delivery of multiple therapeutic agents, and for the simultaneous capability of avoiding biological and biophysiscal barriers. For example, nanoparticles can extravasate into the tumor stroma through the fenestrations of the angiogenic vasculature, demonstrating targeting by enhanced permeation and retention. These particles are able to carry multiple antibodies, which further target them to epitopes on cancer cells, and direct antitumor action, leading to cell death. Irradiation might be use to activate the nanoparticles and set up the release of their cytotoxic action (Ferrari, 2005).

Due to advances in nanobiotechnology, potential therapeutic application of gold nanocarriers represent are an attractive platform for cancer therapy and has been investigated by different coworkers and used in a broad range of applications (Cuenca et al., 2006). Table 2 summarizes the latest progresses and general considerations for AuNP delivery and targeting in cancer therapy, according to their methodology principle, type of incubation/exposure and target organs. In this panorama we can see that over the last 10 years, the majority (approximately 80\%) of gold nanoformulations for gene therapy, tumor targeting and drug delivery in cancer have been tested in cell cultures and normally targeting reporter genes, such as luciferase or GFP. In the future, it is imperative to develop new therapy vehicles and extensive testing in animal models in order to develop the next-generation nanoparticle translation into the clinics. There is only one active clinical trial reporting the use of AuNPs. This phase I trial is studying the side effects and best dose of TNFbound colloidal gold in treating patients with advanced solid tumors (clinical trial number NCT00356980), sponsored by the National Institutes of Health Clinical Center (CC) and National 
Cancer Institute (NCI). As it can be seen in Figure 3 there is a disproportional level between nanoparticle production and their translation into clinics.

In fact, clinical trials require the coordinated effort of interdisciplinary research groups, institutes and pharmaceuticals. Clinical-stage programs will probably have to deal with more and more human data and financial investment, before they can be viewed as a mainstream proposition for resourceful nanotherapy vehicle developers. The current generation of nanoparticles varies widely in size, chemical composition, surface charge, tissue tropism and sensitivity that makes difficult to translate them into the manufacturing process. The community has to learn how to deal with all the dat produced so far. The rules for understanding how nanoparticles interact with different organs and organisms are starting to emerge, although most of the valuable evidences have to come from animal models.

Table 2. Summary of AuNPs used in cancer therapy according to the type of NP, surface modification, type of cancer, target cells/organs/organisms and explored methodology principle.

\begin{tabular}{|c|c|c|c|c|}
\hline Method & $\begin{array}{l}\text { Type of } \\
\text { AuNP }\end{array}$ & Surface modification & $\begin{array}{c}\text { Target } \\
\text { cells/organs/organisms }\end{array}$ & Comments [Reference] \\
\hline \multirow{6}{*}{$\begin{array}{l}\text { Gene } \\
\text { therapy }\end{array}$} & $\begin{array}{c}13 \mathrm{~nm} \\
\text { spherical }\end{array}$ & thiol-ssDNA & $\begin{array}{c}\text { RAW 264.7 } \\
\text { (macrophage); HeLa cells } \\
\text { (cervical carcinoma); NIH- } \\
\text { 3T3 (fibroblast); MDCK } \\
\text { cells (kidney) }\end{array}$ & $\begin{array}{l}\text { In vitro intracellular gene } \\
\text { Regulation; control of protein } \\
\text { expression in cells (Rosi et al., } \\
\text { 2006) }\end{array}$ \\
\hline & $\begin{array}{l}13 \mathrm{~nm} \\
\text { spherical }\end{array}$ & $\begin{array}{l}\text { PEG-block-poly(2-(N,N- } \\
\text { dimethylamino)ethyl } \\
\text { methacrylate) copolymer } \\
\text { (PEG-PAMA); siRNA }\end{array}$ & $\begin{array}{l}\text { HuH-7 cells } \\
\text { (hepatocarcinoma) }\end{array}$ & $\begin{array}{c}\text { Smart PEGylated AuNPs for } \\
\text { the in vitro delivery of siRNA } \\
\text { and to induce gene silencing } \\
\text { (Oishi et al., 2006) }\end{array}$ \\
\hline & $\begin{array}{c}13 \mathrm{~nm} \\
\text { spherical }\end{array}$ & thiol-siRNA & $\begin{array}{l}\text { HeLa cells (cervical } \\
\text { carcinoma) }\end{array}$ & $\begin{array}{l}\text { Polyvalent RNA-nanoparticle } \\
\text { conjugates for in vitro luciferase } \\
\text { knockdown (Giljohann et al., } \\
2009 \text { ) }\end{array}$ \\
\hline & $\begin{array}{c}14 \mathrm{~nm} \\
\text { spherical }\end{array}$ & $\begin{array}{c}\text { thiol-siRNA; naked } \\
\text { siRNA; PEG-COOH; PEG- } \\
\mathrm{N}_{3} ; \text { HIV-derived TAT } \\
\text { peptide; RGD peptide; } \\
\text { quaternary ammonium. }\end{array}$ & $\begin{array}{l}\text { HeLa cells (cervical } \\
\text { carcinoma); (freshwater } \\
\text { polyp, Hydra); mice } \\
(\mathrm{C} 57 \mathrm{BL} / 6 \mathrm{j})\end{array}$ & $\begin{array}{l}\text { In vitro and in vivo } \mathrm{RNAi} \\
\text { triggering using hierarchical } \\
\text { approach with three } \\
\text { biological systems of increasing } \\
\text { complexity (Conde et al., 2012a) }\end{array}$ \\
\hline & $\begin{array}{l}15 \mathrm{~nm} \\
\text { spherical }\end{array}$ & $\begin{array}{l}\text { cationic polymers: PEI; } \\
\text { charge-reversal } \\
\text { PAH-Cit; MUA } \\
\text { (mercaptoundecanoic acid) }\end{array}$ & $\begin{array}{l}\text { HeLa cells (cervical } \\
\text { carcinoma) }\end{array}$ & $\begin{array}{l}\text { Charge-reversal functional } \\
\text { AuNPs to deliver siRNA and } \\
\text { plasmid DNA into cancer cells } \\
\text { (in vitro) (Guo et al., 2010) }\end{array}$ \\
\hline & $\begin{array}{c}14 \mathrm{~nm} \\
\text { spherical }\end{array}$ & Cy3 labeled hairpin-DNA & $\begin{array}{l}\text { HCT-116 cells (carcinoma } \\
\text { of colon) }\end{array}$ & $\begin{array}{l}\text { Au-nanobeacons capable of } \\
\text { intersecting both pathways of in }\end{array}$ \\
\hline
\end{tabular}




\begin{tabular}{|c|c|c|c|c|}
\hline & & & & $\begin{array}{c}\text { vitro RNA interference, blocking } \\
\text { exogenous siRNA and } \\
\text { endogenous microRNA (Conde } \\
\text { et al., 2013b) }\end{array}$ \\
\hline & $\begin{array}{l}13 \mathrm{~nm} \\
\text { spherical }\end{array}$ & $\begin{array}{c}\text { PEG-NH } \mathrm{NH}_{2} ; \operatorname{siRNA} ; \operatorname{poly}(\beta- \\
\text { amino } \\
\text { ester)s (PBAEs) }\end{array}$ & $\begin{array}{l}\text { HeLa cells (cervical } \\
\text { carcinoma) }\end{array}$ & $\begin{array}{c}\text { gold, Poly( } \beta \text {-amino ester) } \\
\text { nanoparticles that facilitate } \\
\text { high levels of } \text { in vitro siRNA } \\
\text { delivery (Lee et al., 2009) }\end{array}$ \\
\hline & $\begin{array}{c}40 \mathrm{~nm} \\
\text { spherical }\end{array}$ & $\begin{array}{l}\text { Protease-degradable poly- } \\
\text { L-lysine (PLL); siRNA }\end{array}$ & $\begin{array}{l}\text { MDA-MB231-luc cells } \\
\text { (breast cancer; LNCaP-luc } \\
\text { cells (prostate } \\
\text { adenocarcinoma) }\end{array}$ & $\begin{array}{l}\text { multilayer siRNA coated AuNPs } \\
\text { using siRNA and PLL as the } \\
\text { charged polyelectrolytes for in } \\
\text { vitro luciferase knockdown (Lee } \\
\text { et al., 2011) }\end{array}$ \\
\hline & $\begin{array}{c}\mathrm{Au}- \\
\text { nanospheres }\end{array}$ & Folate receptor; siRNA & $\begin{array}{l}\text { nude mice bearing HeLa } \\
\text { cervical cancer xenografts }\end{array}$ & $\begin{array}{l}\text { near-IR light-inducible NF- } \\
\text { kappaB in vivo downregulation } \\
\text { through folate receptor-targeted } \\
\text { hollow Au-nanospheres carrying } \\
\text { siRNA recognizing NF-kappaB } \\
\text { p65 subunit (Lu et al., 2010b) }\end{array}$ \\
\hline & $\begin{array}{l}40 \mathrm{~nm} \mathrm{Au}- \\
\text { nanoshells }\end{array}$ & $\begin{array}{c}\text { PEG-NH }{ }_{2} \text {; TAT-lipid; } \\
\text { Cy3-siRNA }\end{array}$ & mouse endothelial cells & $\begin{array}{c}\text { NIR laser-induced release of } \\
\text { siRNA from the nanoshells and } \\
\text { in vitro GFP silencing (Braun et } \\
\text { al., 2009) }\end{array}$ \\
\hline & $\begin{array}{l}\text { spherical } \\
\text { nucleic acid } \\
\text { NP }\end{array}$ & siRNA & $\begin{array}{c}\text { HeLa cells (cervical } \\
\text { carcinoma); SKH-1E and } \\
\text { C57BL/6J mice }\end{array}$ & $\begin{array}{c}\text { In vitro and in vivo topical } \\
\text { delivery of siRNA-based } \\
\text { spherical nucleic acid AuNP } \\
\text { conjugates for gene regulation } \\
\text { (Zheng et al., 2012) }\end{array}$ \\
\hline \multirow{7}{*}{$\begin{array}{l}\text { Tumor } \\
\text { targeting }\end{array}$} & spherical & $\begin{array}{l}\text { pH Low Insertion Peptide } \\
\text { (pHLIP) }\end{array}$ & Mouse model & $\begin{array}{c}\text { nanogold-pHLIP conjugates used } \\
\text { in vivo to target tumors (Yao et } \\
\text { al., 2013) }\end{array}$ \\
\hline & $\begin{array}{c}6 \mathrm{~nm} \\
\text { spherical }\end{array}$ & $\begin{array}{c}\text { amine-terminated } \\
\text { generation 5 (G5) } \\
\text { poly(amidoamine) } \\
\text { (PAMAM) dendrimers pre- } \\
\text { functionalized with folic } \\
\text { acid (FA) and fluorescein } \\
\text { isothiocyanate (FI) }\end{array}$ & $\begin{array}{l}\text { KB-HFAR cells (human } \\
\text { epithelial carcinoma) }\end{array}$ & $\begin{array}{l}\text { multifunctional dendrimer- } \\
\text { stabilized AuNPs can } \\
\text { specifically target cancer cells } \\
\text { expressing high-affinity FA } \\
\text { receptors in vitro (Shi et al., } \\
\text { 2009) }\end{array}$ \\
\hline & $\begin{array}{c}30 \mathrm{~nm} \\
\text { spherical }\end{array}$ & $\begin{array}{l}\text { PEGylated trastuzumab } \\
\text { (Herceptin) }\end{array}$ & $\begin{array}{l}\text { MDA-MB-361 (breast } \\
\text { cancer) tumors }\end{array}$ & $\begin{array}{l}\text { Human Epidermal Growth } \\
\text { Factor Receptor-2 (HER-2)- } \\
\text { targeted AuNPs that enhance the } \\
\text { radiation response of in vitro } \\
\text { breast cancer cells and in vivo } \\
\text { tumor xenografts to X-radiation } \\
\text { (Chattopadhyay et al., 2013) }\end{array}$ \\
\hline & $\begin{array}{c}4 \mathrm{~nm} \\
\text { spherical }\end{array}$ & VEGF antibody (AbVF) & $\begin{array}{l}\text { CLL B cells (B-Chronic } \\
\text { Lymphocytic Leukemia) }\end{array}$ & $\begin{array}{c}\text { AuNPs enhance in vitro } \\
\text { apoptosis in B-chronic } \\
\text { lymphocytic leukemia } \\
\text { (Mukherjee et al., 2007) }\end{array}$ \\
\hline & $\begin{array}{c}60 \mathrm{~nm} \\
\text { spherical }\end{array}$ & $\begin{array}{l}\text { PEG-COOH; malachite } \\
\text { green isothiocyanate } \\
\text { (MGITC); ScFv B10 } \\
\text { (antibody fragment for } \\
\text { human EGFR) } \\
\end{array}$ & $\begin{array}{l}\text { Tu686 and H520 cells } \\
\text { (EGFR-positive cancer } \\
\text { cells); nude mouse } \\
\text { xenografted with Tu686 } \\
\text { cells } \\
\end{array}$ & $\begin{array}{l}\text { Pegylated SERS AuNPs for in } \\
\text { vitro and in vivo tumor targeting } \\
\text { and detection (Qian et al., 2008a) }\end{array}$ \\
\hline & $\begin{array}{l}\text { Ultra-small } \\
\text { Au- } \\
\text { nanoclusters }\end{array}$ & $\begin{array}{l}\text { folic acid (FA); near- } \\
\text { infrared fluorescent dye } \\
\text { (MPA); Doxorubicin } \\
\text { (DOX) }\end{array}$ & $\begin{array}{l}\text { A549 cells (lung cancer); } \\
\text { HepG-2 (liver cancer); } \\
\text { MDA-MB-231 (breast } \\
\text { cancer); HTC } 116 \\
\text { (carcinoma of colon) }\end{array}$ & $\begin{array}{l}\text { Cellular and in vivo studies with } \\
\text { Au-FA-MPA and Au-FA-DOX } \\
\text { show high affinity and anti- } \\
\text { tumor activity to different tumors } \\
\text { (Chen et al., 2012) }\end{array}$ \\
\hline & $30 \mathrm{~nm}$ & PEGylated trastuzumab & MDA-MB-361 cells (breast & AuNPs that enhance tumor \\
\hline
\end{tabular}




\begin{tabular}{|c|c|c|c|c|}
\hline & spherical & $\begin{array}{c}\text { (FDA-approved } \\
\text { humanized monoclonal } \\
\text { antibody); radiolabeled } \\
\text { polymer }\end{array}$ & $\begin{array}{c}\text { cancer); athymic CD-1 mice } \\
\text { bearing MDA-MB- } \\
\text { 361tumors }\end{array}$ & $\begin{array}{c}\text { uptake and intracellular delivery } \\
\text { (in vitro and in vivo) while } \\
\text { reducing the systemic exposure } \\
\text { by evaluation of the impact of } \\
\text { targeting and route of } \\
\text { administration on organ } \\
\text { distribution (Chattopadhyay et } \\
\text { al., 2012) } \\
\end{array}$ \\
\hline \multirow{8}{*}{$\begin{array}{c}\text { Drug } \\
\text { delivery }\end{array}$} & $\begin{array}{l}2.5 \mathrm{~nm} \\
\text { spherical }\end{array}$ & $\begin{array}{c}\text { hydrophobic drugs: } \\
\text { tamoxifen (TAF) } \\
\text { and } \beta \text {-lapachone (LAP); } \\
\text { Bodipy (fluorescent probe) }\end{array}$ & MCF-7 cells (breast cancer) & $\begin{array}{l}\text { Entrapment of hydrophobic } \\
\text { drugs in AuNP monolayers with } \\
\text { efficient in vitro release into } \\
\text { cancer cells (Kim et al., 2009a) }\end{array}$ \\
\hline & $\begin{array}{l}30 \mathrm{~nm} \\
\text { spherical }\end{array}$ & $\begin{array}{c}\text { prostate-specific membrane } \\
\text { antigen (PSMA) RNA } \\
\text { aptamer; Doxorubicin } \\
\text { (DOX) }\end{array}$ & $\begin{array}{l}\text { LNCaP cells (prostate } \\
\text { adenocarcinoma) }\end{array}$ & $\begin{array}{l}\text { A drug-loaded aptamer-AuNP } \\
\text { bioconjugate for in vitro imaging } \\
\text { and therapy of prostate cancer } \\
\text { (Kim et al., 2010) }\end{array}$ \\
\hline & $\begin{array}{l}25 \mathrm{~nm} \\
\text { spherical }\end{array}$ & $\begin{array}{l}\text { thiol-PEGylated; } \\
\text { tamoxifen (TAM) }\end{array}$ & $\begin{array}{l}\text { MDA-MB-361 cells (breast } \\
\text { cancer); MCF-7 cells (breast } \\
\text { cancer) }\end{array}$ & $\begin{array}{l}\text { Tamoxifen-poly(ethylene } \\
\text { glycol)-thiol AuNPs that } \\
\text { enhance potency and selective } \\
\text { delivery for in vitro breast cancer } \\
\text { treatment (Dreaden et al., 2009) }\end{array}$ \\
\hline & $\begin{array}{l}180 \mathrm{~nm} \\
\text { spherical }\end{array}$ & PEG; Oxaliplatin & $\begin{array}{l}\text { A549 cells (lung epithelial } \\
\text { cancer); HCT116, HCT15, } \\
\text { HT29, RKO cells (all for } \\
\text { colon cancer) }\end{array}$ & $\begin{array}{l}\text { AuNPs for the improved } \\
\text { anticancer drug delivery in vitro } \\
\text { of the active component of } \\
\text { oxaliplatin (Brown et al., 2010) }\end{array}$ \\
\hline & $\begin{array}{c}13 \mathrm{~nm} \\
\text { spherical }\end{array}$ & cisplatin & $\begin{array}{l}\text { A549 cells (lung cancer); } \\
\text { tumor-bearing SCID mice }\end{array}$ & $\begin{array}{l}\text { In vitro and in vivo antitumoral } \\
\text { drugs conjugated to AuNPs } \\
\text { (Comenge et al., 2012) }\end{array}$ \\
\hline & spherical & Cyclic peptide & $\begin{array}{l}\text { CCRF-CEM cells (human } \\
\text { leukemic lymphoblasts); } \\
\text { SK-OV-3 cells (human } \\
\text { ovarian adenocarcinoma) }\end{array}$ & $\begin{array}{l}\text { Cyclic peptide-capped AuNPs } \\
\text { for in vitro drug delivery } \\
\text { (Nasrolahi et al., 2012) }\end{array}$ \\
\hline & $\begin{array}{l}40 \mathrm{~nm} \text { Au- } \\
\text { nanospheres }\end{array}$ & $\begin{array}{c}\mathrm{NH}_{2} \text {-PEG-COOH; } \\
\text { Doxorubicin (DOX); } \\
\text { Cyclic peptide c(TNYL- } \\
\text { RAW), a second- } \\
\text { generation EphB4-binding } \\
\text { antagonist }\end{array}$ & mice bearing Hey tumors & $\begin{array}{c}\text { In vivo photothermal } \\
\text { chemotherapy using } \\
\text { doxorubicin-loaded Au- } \\
\text { nanospheres that target EphB4 } \\
\text { receptors in tumors (You et al., } \\
\text { 2012) }\end{array}$ \\
\hline & $\begin{array}{l}\text { plasmonic } \\
\text { vesicles } \\
\text { assembled } \\
\text { from } 14 \mathrm{~nm} \\
\text { spherical } \\
\text { AuNPs }\end{array}$ & $\begin{array}{l}\text { Raman reporter; PEG; } \\
\text { hydrophobic copolymer } \\
\text { (PMMAVP) of methyl } \\
\text { methacrylate (MMA) and } \\
\text { 4-vinylpyridine (4VP) }\end{array}$ & $\begin{array}{l}\text { SKBR-3 cells (breast } \\
\text { adenocarcinoma) }\end{array}$ & $\begin{array}{l}\text { Self-assembled plasmonic } \\
\text { vesicles of SERS-encoded } \\
\text { amphiphilic AuNPs for in vitro } \\
\text { cancer cell targeting and } \\
\text { traceable intracellular drug } \\
\text { delivery (Song et al., 2012) }\end{array}$ \\
\hline
\end{tabular}

\subsection{Gene therapy}

We are in the dawn of a new age in gene therapy driven by nanotechnology vehicles. Although there are technical challenges associated with the therapeutic application of nanoparticles, the integration of therapy with diagnostic profiling has accelerated the pace of discovery of new nanotechnology 
methods. The development of a safe, efficient, specific and nonpathogenic vehicle for gene delivery is highly attractive (Akhtar and Benter, 2007;Kim et al., 2009b).

Gene therapy is receiving increasing attention and, in particular, small-interference RNA (siRNA) shows importance in novel molecular approaches in the knockdown of specific gene expression in cancerous cells. In fact, this non-viral-vector-mediated delivery of therapeutic siRNAs is highly desirable and constitutes an important challenge to gene therapy (Castanotto and Rossi, 2009;Li et al., 2002;Soutschek et al., 2004).

In fact, antisense DNA (Fichou and Ferec, 2006; Toub et al., 2006) and RNA interference (RNAi) via the use of small-interfering RNA (Fire et al., 1998;Baker, 2010;Milhavet et al., 2003;Wall and Shi, 2003) have emerged as powerful and useful tools to block gene function and for sequence-specific posttranscriptional gene silencing, playing an important role in downregulation of specific gene expression in cancer cells. Thus, one drawback of using naked siRNAs is that they show extremely short half-lives, weak protection against action by RNases, poor chemical stability, and common dissociation from vector (Hannon and Rossi, 2004). In fact, the major obstacle to clinical application is the uncertainty about how to deliver therapeutic RNAs (e.g., miRNA and/or siRNA) with maximal therapeutic impact. AuNPs have shown potential as intracellular delivery vehicles for antisense oligonucleotides (e.g., miRNA and/or siRNA) with maximal therapeutic impact. AuNPs have shown potential as intracellular delivery vehicles for antisense oligonucleotides (Rosi et al., 2006) and for therapeutic siRNA by providing protection against RNAses and ease of functionalization for selective targeting (Giljohann et al., 2009; Whitehead et al., 2009). For example, Mirkin and coworkers reported the use of polyvalent RNA-AuNP conjugates that are readily taken up by cells and that the particle bound siRNA can effectively regulate genes in the context of RNA interference (Giljohann et al., 2009).

Several other studies using engineered NPs modified with siRNA have demonstrated a cytoplasmic delivery system of siRNA and efficient gene silencing using AuNPs (Giljohann et al., 2009; Lee et 
al., 2009; Guo et al., 2010; Lee et al., 2008). However, almost all nanoconjugates using siRNA have exclusively been tested in cell cultures targeting only reporter genes.

Recently, Conde et al. provided evidence of in vitro and in vivo RNAi triggering via the synthesis of a library of novel multifunctional AuNPs, using a hierarchical approach including three biological systems of increasing complexity: in vitro cultured human cells, in vivo freshwater polyp (Hydra vulgaris), and in vivo mice models (Conde et al., 2012a). The authors developed effective conjugation strategies to combine, in a highly controlled way, specific biomolecules to the surface of AuNPs such as: (a) biofunctional spacers: Poly(ethylene glycol) (PEG) spacers used to increase solubility and biocompatibility; (b) cell penetrating peptides such as TAT and RGD peptides: A novel class of membrane translocating agents named cell penetrating peptides (CPPs) that exploit more than one mechanism of endocytosis to overcome the lipophilic barrier of the cellular membranes and deliver large molecules and even small particles inside the cell for their biological actions; and (c) siRNA complementary to a master regulator gene, the protooncogene c-myc, were bond covalently (SH-siRNA) and ionically (naked/unmodified siRNA) to AuNPs (Conde et al., 2012a).

However, efforts to target siRNA-nanoparticles to organs are less advanced. Some organs need smaller and novel NPs to access different kinds of tissue. Another challenge, which also requires novel materials, is the endosomal release of siRNA, once it is transported across the cell membrane. Most of the described systems also get trapped by the the lysosomes and their siRNA cargo gets compromised. Probably the endosomal escape or siRNA accessibility to form the RNA-induced silencing complex (RISC) requires substantially more circulation time.

While the AuNPs for gene therapy discussed thus far employ the load of siRNA to nanoparticles, AuNPs have also shown potential as intracellular delivery vehicles for antisense oligonucleotides (ssDNA,dsDNA) by providing protection against intracellular nucleases and ease of functionalization for selective targeting (Whitehead et al., 2009; Giljohann et al., 2009). So far, 
several strategies for gene delivery systems have been developed, including mixed monolayer protected AuNPs (Rana et al., 2012; Ghosh et al., 2008b), polymer-AuNPs complexes (Thomas and Klibanov, 2003b;Ghosh et al., 2008c) and dsDNA and ssDNA functionalized AuNPs (Conde et al., 2010a;McIntosh et al., 2001).

Recently, Conde et al developed a new theranostic system capable of intersecting all RNA pathways: from gene specific downregulation to silencing the silencers, i.e. siRNA and miRNA pathways. The authors reported the development AuNPs functionalized with a fluorophore labeled hairpin-DNA, i.e. Gold nanobeacons, capable of efficiently silencing single gene expression, exogenous siRNA and endogenous miRNAs while yielding a quantifiable fluorescence signal directly proportional to the level of silencing (Conde et al., 2013b).

From a synthetic point of view it is still unclear the differences between DNA-AuNPs and siRNAAuNPs. From the papers reported so far the siRNA and DNA gold nanoconjuates are almost from the same size and charge, and show similar efficiencies. Nevertheless siRNA-AuNP conjugates require functionalization with thiol-PEG molecules to achieve equivalent stability to DNA-AuNPs, which may have something to do with the capacity loading of the different molecules due to singular hydrophobicity and/or hydrophilicity, molecular weight and charge density properties between RNA and DNA (Gary et al., 2007). However, this fact needs additional clarification.

Further research into the fundamental mechanisms of in vivo gene therapy using nanodevices could unveil new dimensions of nanoparticle-mediated gene silencing that will have profound implications for understanding gene regulation, and which could also affect the development of functional genomics and therapeutic applications. One of the most important issues that is still unclear is how biocompatible AuNPs will be following intraveneous injection, in particular when the ultimate destination is the cytoplasm and/or nucleus inside cells. Future in vivo work will need to cautiously consider the accurate option of chemical modifications to incorporate into the nanoparticles to avoid off-target effects. Though nanoparticles' potential against cancer is still in need of further 
optimization and characterization, it is now time to start translating these promising platforms to the clinical settings towards widespread effective therapy strategies in the fight against cancer.

\subsection{Tumor targeting}

Nanoparticles are excellent tumor-targeting vehicles because of a unique inherent property of solid tumors. Numerous tumors present with defective vasculature and poor lymphatic drainage, due to the rapid growth of solid tumors, resulting in an enhanced permeability and retention effect. This effect allows nanoparticles to accumulate specifically at the tumor site (Minelli et al., 2010;Gil and Parak, 2008). Once the tumor is directly connected to the main blood circulation system, multifunctional nanocarriers can exploit several characteristics of the newly formed vasculature and efficiently target tumors. Tumor cells are supplied by blood capillaries that perfuse the cells of the tissue where nanocarriers can passively accumulate or anchor through targeting moieties to biomarkers overexpress by tumor cells (Conde et al., 2012b).

Shi et al. developed a simple system with multifunctional amine terminated poly(amidoamine) (PAMAM) dendrimers, folic acid (FA) and fluorescein isothiocyanate functionalized in gold nanoparticles. This approach can specifically target cancer cells expressing high-affinity FA receptors in vitro (Shi et al., 2009).

Further work in tumor targeting was reported in a subcutaneous model of colon cancer, where it was demonstrated that systemically delivered AuNPs (size, approximately $33 \mathrm{~nm}$ ) conjugated to tumor necrosis factor (TNF) accumulated in tumors (Paciotti et al., 2004). This study outlines the development of a colloidal gold nanoparticle vector that targets the delivery of tumor necrosis factor (TNF) to a solid tumor growing in mice.

Mukherjee et al. studied B-Chronic Lymphocytic Leukemia (CLL) which is characterized by apoptosis resistance. They found induction of significantly more apoptosis in CLL B cells by coculture with an anti-VEGF antibody. To increase the efficacy of these agents in CLL therapy they 
focused on the use of AuNPs, by attaching VEGF antibody to the nanoparticle's surface. The AuNP-VEGF antibody treated cells showed significant down regulation of anti-apoptotic proteins (Mukherjee et al., 2007).

In cancer research, colloidal gold can be used to target tumors and provide detection using SERS (Surface Enhanced Raman Spectroscopy) in vivo. These AuNPs are surrounded with Raman reporters which provide light emission that is over 200 times brighter than quantum dots (Cai et al., 2008;Kneipp et al., 2006). It was found that the Raman reporters were stabilized when the nanoparticles were encapsulated with a thiol-modified polyethylene glycol coat and gave large optical enhancements. This allows for compatibility and circulation in vivo. When conjugated to tumor-targeting ligands, these conjugated SERS nanoparticles were able to target tumor markers such as epidermal growth factor receptor (EGFR), which is sometimes overexpressed in cells of certain cancer types, (El-Sayed et al., 2006;El-Sayed et al., 2005a) and then detect the location of the tumor on human cancer cells and in xenograft tumor models (Qian et al., 2008a). Qian et al. described biocompatible and nontoxic nanoparticles for in vivo tumor targeting and detection based on pegylated gold nanoparticles and surface-enhanced Raman scattering. These conjugated nanoparticles were able to target tumor biomarkers such as epidermal growth factor receptors on human cancer cells and in xenograft tumor models (Qian et al., 2008a).

Although cancer therapies are improving, some formulations are not reaching with high efficiency tumor cells or tissues, and countless doubts remains over the efficacy of those that do. To efficiently target a cancer cell, either a circulation cell or a cell from the primary tumor or one hidden within a population of normal cells, represents an exceptional challenge. In fact, there are a lot of limitations for tumor targeting as some nanocarriers can also target normal proteins which are not exclusively expressed by the cancer cell. Targeting specific cells may be completely different to target the organ. The most important aspects that the researchers need to take into account are the specificity of the nanoparticle to the target molecules, as well as toxicological and immunological effects (Schroeder 
et al., 2012). For example, the combination of small size nanoparticles with their special thermal, imaging, drug/gene carrier, or optical characteristics with the specific and selective recognition abilities of antibodies will definitely produce a hybrid product that shows versatility and specificity. Actually, Conde et al reported the evaluation of the inflammatory response and therapeutic siRNA silencing via RGD-nanoparticles in a lung cancer mouse model (Conde et al., 2013c). This study reported the use of siRNA/RGD gold nanoparticles capable of targeting tumor cells in two lung cancer xenograft mouse models, resulting in successful and significant $c-M y c$ oncogene downregulation followed by tumor growth inhibition and prolonged survival of the animals. This delivery system can achieve translocation of siRNA duplexes directly into the tumour cell cytoplasm and accomplish successful silencing of an oncogene expression. Actually, RGD/siRNA-AuNPs can target preferentially and be taken up by tumor cells via integrin $\alpha v \beta 3$-receptor-mediated endocytosis with no cytotoxicity, showing that can accumulate in tumor tissues overexpressing $\alpha v \beta 3$ integrins and selectively delivered $c-M y c$ siRNA to suppress tumor growth and angiogenesis (Conde et al., 2013c).

Therefore, multifunctional nanocarriers have the potential to join numerous therapeutic functions into a single platform, by targeting specific tumor cells, tissues and organs.

\subsection{Drug delivery}

The vast majority of FDA approved used drugs exhibit a short half-life in the blood stream and a high overall clearance rate. In fact, the major obstacles/limitations in drug delivery are: cytoplasmic and systemically delivery of the drug, renal clearance, target site accumulation after administration and heterogeneous vascular perfusion and diffusion. Actually, these small drug molecules usuaaly diffuse rapidly into healthy tissues and are dispersed consistently within the body. As a consequence, just a small amount of the drug can reach the target site, which often leads to side effects. These obstacles usually occur with drugs that exhibit a narrow therapeutic index, such as anticancer 
biomolecules, immunosuppressive agents, as well as antirheumatic medicines. Poor drug delivery and accumulation at the target site frequently leads to significant limitations, such as multi-drug resistance, which leads many cancers to develop severe resistance to chemotherapy drugs (Ehdaie, 2007).

Nanocarriers can be used to optimize the biodistribution of drugs to diseased organs, tissues or cells, in order to improve and target drug delivery (Han et al., 2007b).

It is important to realize that the nanoparticle-mediated drug delivery is feasible only if the drug distribution is otherwise inadequate. These cases include drug targeting of difficult, unstable molecules (proteins, siRNA, DNA), delivery to the difficult sites (brain, retina, tumors, intracellular organelles) and drugs with serious side effects (e.g. anti-cancer agents). The performance of the nanoparticles depends on the size and surface functionalities in the particles. Also, the drug release and particle disintegration can vary depending on the system (eg. biodegradable polymers sensitive to $\mathrm{pH})$. An optimal nanodrug delivery system ensures that the active drug is available at the site of action for the correct time and duration, and their concentration should be above the minimal effective concentration (MEC) and below the minimal toxic concentration (MTC) (Han et al., 2007a;Langer, 2000).

AuNPs are also being investigated as vehicles for drug delivery such as paclitaxel (Gibson et al., 2007). Gibson et al. describe the first example of $2 \mathrm{~nm}$ AuNPs covalently functionalized with the chemotherapeutic drug paclitaxel. The administrations of hydrophobic drugs require molecular encapsulation and it is found that nanosized particles are particularly efficient in evading the reticuloendothelial system. This approach gives a rare opportunity to prepare hybrid particles with a well-defined amount of drug and offers a new alternative for the design of nanosized drug-delivery systems (Kim et al., 2009a;Hwu et al., 2009;Gibson et al., 2007) (see Figure 4) Nanotechnology has provided for novel and powerful systems that may be used treatment of human diseases. However the majority of products, reagents and drugs being used for the development of 
these nanoscale systems have to be approved by the main supervising agencies, such as the FDA and EMA (Baptista, 2009).

Thus far, some limitations for the correct design and application of nanoparticles, such as pharmacokinetics, biodistribution, and side effects of the nanotherapy; safety profile of nanoparticles before and after conjugation and toxicity, needs to be clarified to validate efficient clinical appliance (Baptista, 2009).

\section{NanoToxicity}

The AuNPs have a proclivity in vivo and in vitro to bioaccumulate within various types of cells with a special affinity for macrophage-type cells (both histiocytes and blood phagocytic cells), and reticuloendothelial cells throughout the body). They also produce varying degrees of bioaccumulation in such tissues as lymph nodes, bone marrow, spleen, adrenals, liver and kidneys (Lasagna-Reeves et al., 2010;Chen et al., 2009;Dobrovolskaia et al., 2008).

Research shows that nanoparticles can stimulate and/or suppress the immune responses, and that their compatibility with the immune system is largely determined by their surface chemistry. In fact, is well known the influence of size, solubility and surface modification on the biocompatibility of nanoparticles and their use in biological applications (Dobrovolskaia and McNeil, 2007) (see Figure 5).

AuNPs are generally considered to be benign. However, the size similarity of AuNPs to biological matters could provide "camouflage" to cellular barriers, leading to undesired cellular entry which might be detrimental to normal cellular function (Connor et al., 2005).

Pan and colleagues recently conducted a systematic investigation of the size-dependent cytotoxicity of AuNPs against four cell lines (Pan et al., 2007). They found that AuNPs 1 to $2 \mathrm{~nm}$ in size displayed cell-type dependent cyotoxicity with high micromolar IC50s. In contrast, AuNPs $15 \mathrm{~nm}$ in size were nontoxic to cells at concentrations 60-fold higher than the IC50 of the smaller AuNPs. 
These results seemed to confirm size dependent toxicity of AuNPs (Kim et al., 2009a;Visaria et al., 2006;Paciotti et al., 2004;El-Sayed et al., 2005b;Huang et al., 2008), an inference that has hitherto been somewhat ambivalent. On the other hand, found that the presence of sodium citrate residues on AuNPs impaired the viability in the alveolar type-II cell lines A549 and NCIH441. Interestingly, the presence of an excess of sodium citrate on the surface of NPs not only reduced the in vitro viability of A549 and NCIH441cell lines, but also affected cellular proliferation and increased the release of lactate dehydrogenase (marker for apoptotic cell degradation) (Uboldi et al., 2009).

Although AuNPs are generally considered as highly biocompatible, previous in vitro studies have also shown that cytotoxicity of AuNPs in certain human epithelial cells was observed (Freese et al., 2012; Rothen-Rutishauser et al., 2007).

Now the most urgent questions rise up. Are the gold nanoparticles cytotoxic or biocompatible? And how can the gold nanoparticles be design to avoid these effects?

There does not seem to have a simple answer. Even though there is not any general mechanism for making nanoparticles universally 'non-toxic' to all living cells and all organisms, there are important findings that can be applied for increasing nanoparticle biocompatibility and reducing cytotoxic interactions in vivo and in vitro.

Using the lowest nanoparticle dose to get the desired response for the shortest period of time, in general, seems to promote biocompatibility as well as coating a nanoparticle if the outer coating completely covers the nanoparticle reactive surface (a non-continuous covering, the presence of cracks, roughness or interruptions could lead to complement or antibody attachment, or dissolution of the coating by cell digestion), and cannot be removed and utilized by the living cell (Bellucci, 2009).

It is essential to test nanoparticle/biological interactions experimentally and modify the nanoparticles for best biocompatibility with the cell in order to eliminate some obstacle, like the peroxidation of membrane lipids, the generation of reactive oxygen species, the acute and chronic release of pro- 
inflammatory factors, modification in genetic cellular function, and the possibility of nanoparticles becoming inactive/unavailable during filtration or passage through pores and fenestrations (Sun et al., 2005) due to size, inflexibility of the nanoparticle core, or protein adsorption and agglomeration (Bellucci, 2009).

When interpreting nanoparticle interactions with cells and organisms, it is important to remember that living systems may appear normal and be capable of growth and function, but they may be genetically altered in subtle ways following nanoparticle exposure, which can produce serious consequences at some time in the distant future. Conversely, other cells that seem to be damaged may, in time, recover from nanoparticle exposure and function normally in the absence of the nanoparticles (Bellucci, 2009).

In conclusion, the only weapon that we have to insure that these new materials are well designed and safely used is to question and test each new nanoparticle to make sure that it has been designed for safety (with maximum biocompatibility) during handling, use and disposal. Evaluating the biocompatibility of nanomaterials is imperative. In fact, it is important to carefully characterize the biocompatibility and safety of the nanomaterials if they are to be used for medical purposes. Despite the major scientific advances made in the field of molecular and cell biology and biotechnology, the basic concepts of regulatory toxicology have hardly changed over the past decades (Dobrovolskaia and McNeil, 2007). Actually, the vast majority of studies report the biocompatibility of nanomaterials only trough the study of cell viability. Almost no importance is given when testing nanomaterials in the detection of genetic damages (DNA strand breaks and the formation of nuclear abnormalities), or in identifying protein markers of toxicity, or measuring the level of oxidative stress. For example, when using gene silencing technologies, the function of specific genes and proteins in toxicity pathways could be identified, once DNA-damage response (DNA repair, cellcycle regulation and apoptosis) encompasses gene-expression regulation at the transcriptional and post-translational levels. 
In fact, Conde et al. reported a gold-nanobeacon system (Conde et al., 2013b) used for gene therapy that was extensively evaluated for the genotoxic, cytotoxic and proteomic effects after incubation in cancer cells (Conde et al., 2013a). The exposure was evaluated by two-dimensional protein electrophoresis followed by mass spectrometry to perform a proteomic profile and MTT assay, glutathione-S-transferase assay, micronucleus test and comet assay to assess the genotoxicity. An assessment of genome-related toxicity revealed no significant DNA damage increase, as well as no potential mutagenic or clastogenic consequences to the cell (Conde et al., 2013a).

\section{Conclusions and Future perspectives}

Over the last decade, thousands of different gold nanocarriers were developed and published. Almost $20 \%$ of these papers were published in 2010 alone. It is indisputable that the use of gold nanocarriers has been gaining momentum as vectors for therapy and diagnostic strategies, combining the AuNPs' ease of functionalization with numerous biomolecules, high loading capacity and fast uptake by target cells.

Here, we have reviewed part of this exciting progress and research advances within the context of multifunctional gold nanocarriers for cancer theranostics. Despite the significant efforts towards the use of gold nanocarriers in biologically relevant research, more in vivo studies are needed to assess the applicability of these materials as delivery agents. In fact, only a few went through feasible clinical trials. Nanoparticles have to serve as the norm rather than an exception in the future conventional cancer treatments. Future in vivo work will need to carefully consider the correct choice of chemical modifications to incorporate into the multifunctional gold nanocarriers to avoid activation off-target, side effects and toxicity. Moreover the majority of studies on nanomaterials do not consider the final application to guide the design and functionalization of NP. Instead, the focus is predominantly on engineering materials with specific physical or chemical properties. 
Although great effort has been applied to the detection of microorganisms and/or virus using gold biosensors only a few were used for the detection of chronic diseases, such as cancer. The lack of specific and unique DNA/RNA markers and the complexity of the intricate regulation pathways have made the development of probes rather difficult. Particularly in cancer, future trends need to be focused on the detection of microRNAs and circulating DNA biomarkers or the recognition of circulating tumor cells followed by a detection step. Since most of the nanodiagnostic systems report DNA sequence analysis/detection, the great majority ignored the important genomic and transcriptomic information when detecting messengerRNA and microRNAs, which are considered to be excellent biomarkers for the early diagnosis of cancer.

To improve medicine, scientific discoveries must be translated into clinical applications. Such discoveries typically begin at "the bench" with basic/fundamental research in which scientists study disease at a molecular or cellular level then progress to the clinical level, which is the patient's "bedside". Scientists and clinicians are increasingly aware that this bench-to-bedside approach to translational research is really a two-way interaction. However, an additional effort should appear towards the development of new clinical strategies.

Moreover, the systems discussed here are each of them unique in many aspects. Some of the nanoformulations have very well defined structures, whereas some are highly heterogeneous. Some have a wide range of size, charge and surface. This raises the important question about the reliability of their production protocols. The great majority of the nanosystems described here presents or will present additional challenges in the scale-up of the manufacturing process. Besides, central concerns about nanoparticle's biodistribution and the proper considerations of safety for the patients.

Therefore, the establishment of safe regulatory approval nanoformulations turns to be essential. For that reason, it is imperative to learn how advances in nanosystem's capabilities are being used to identify new diagnostic and therapy tools driving the development of personalized medicine in oncology; discover how integrating cancer research and nanotechnology modeling can help patient 
diagnosis and treatment; recognize how to translate nanotheranostics data into an actionable clinical strategy; discuss with industry leaders how nanotheranostics is evolving and what the impact is on current research efforts; and last but not least, learn what approaches are proving fruitful in turning promising clinical data into treatment realities.

Although all studies described here provide a baseline level of data in support of the effectiveness and safety of nanomaterials, we wonder how useful the data generated will be in successfully predicting and preventing scientists from jeopardizing the safety of the future patients?

With chemists, biologists and materials scientists working together with clinicians and engineers, but especially with "translational innovators" new solutions to crucial nanobiomedical problems will hopefully be found.

\section{Competing interests}

The authors declare that they have no competing interests.

\section{Authors' contributions}

JC conceptualized the manuscript and wrote the draft. FT, PVB and JMF contributed in the draft and concept of the paper. All authors contributed in the revision process. All authors read and approved the final manuscript.

\section{Acknowledgements}

Authors thank ERANET-NANOSCIERA NANOTRUCK project for financial support. JC acknowledges FCT grant (SFRH/BD/62957/2009). JMF thanks ARAID and Fondo Social Europeo for financial support. PVB thanks CIGMH/FCT/MCES (PEst-OE/SAU/UI0009/2011). 


\section{Reference List}

http://nano.cancer.gov/. Nanotechnology . 2010.

Ref Type: Electronic Citation

Akhtar S, Benter IF (2007) Nonviral delivery of synthetic siRNAs in vivo. J Clin Invest 117:36233632

Alvarez-Puebla RA, Liz-Marzan LM (2010) SERS-Based Diagnosis and Biodetection. Small 6:604610

Alvarez-Puebla RA, Liz-Marzan LM (2012a) SERS Detection of Small Inorganic Molecules and Ions. Angewandte Chemie-International Edition 51:11214-11223

Alvarez-Puebla RA, Liz-Marzan LM (2012b) Traps and cages for universal SERS detection. Chemical Society Reviews 41:43-51

Ambrosi A, Airo F, Merkoci A (2010) Enhanced gold nanoparticle based ELISA for a breast cancer biomarker. Anal Chem 82:1151-1156

Arruebo M, Valladares M, Gonzalez-Fernandez A (2009) Antibody-Conjugated Nanoparticles for Biomedical Applications. Journal of Nanomaterials

Baker M (2010) RNA interference: From tools to therapies. Nature 464:1225

Baptista P (2009) Cancer Nanotechnology - Prospects for Cancer Diagnostics and Therapy. Current Cancer Therapy Reviews

Baptista P, Doria G, Henriques D, Pereira E, Franco R (2005) Colorimetric detection of eukaryotic gene expression with DNA-derivatized gold nanoparticles. J Biotechnol 119:111-117

Baptista P, Pereira E, Eaton P, Doria G, Miranda A, Gomes I, Quaresma P, Franco R (2008) Gold nanoparticles for the development of clinical diagnosis methods. Anal Bioanal Chem 391:943-950

Baptista PV (2012) Could gold nanoprobes be an important tool in cancer diagnostics? Expert Review of Molecular Diagnostics 12:541-543

Baptista PV, Koziol-Montewka M, Paluch-Oles J, Doria G, Franco R (2006) Gold-nanoparticleprobe-based assay for rapid and direct detection of Mycobacterium tuberculosis DNA in clinical samples. Clin Chem 52:1433-1434

Bellucci S (2009) Nanoparticles and Nanodevices in Biological Applications, Lecture Notes in Nanoscale Science and Technology edn. Springer,

Braun GB, Pallaoro A, Wu G, Missirlis D, Zasadzinski JA, Tirrell M, Reich NO (2009) LaserActivated Gene Silencing via Gold Nanoshell-siRNA Conjugates. ACS Nano 
Brown SD, Nativo P, Smith JA, Stirling D, Edwards PR, Venugopal B, Flint DJ, Plumb JA, Graham D, Wheate NJ (2010) Gold nanoparticles for the improved anticancer drug delivery of the active component of oxaliplatin. J Am Chem Soc 132:4678-4684

Cai, W., Gao, T., Hong, H., and Sun, Jiangtao. Applications of gold nanoparticles in cancer nanotechnology. Nanotechnology Science and Applications 1, 17-32. 2008.

Ref Type: Journal (Full)

Cao YC, Jin R, Thaxton CS, Mirkin CA (2005) A two-color-change, nanoparticle-based method for DNA detection. Talanta 67:449-455

Castaneda MT, Merkoci A, Pumera M, Alegret S (2007) Electrochemical genosensors for biomedical applications based on gold nanoparticles. Biosens Bioelectron 22:1961-1967

Castanotto D, Rossi JJ (2009) The promises and pitfalls of RNA-interference-based therapeutics. Nature 457:426-433

Chattopadhyay N, Cai ZL, Kwon YL, Lechtman E, Pignol JP, Reilly RM (2013) Molecularly targeted gold nanoparticles enhance the radiation response of breast cancer cells and tumor xenografts to X-radiation. Breast Cancer Research and Treatment 137:81-91

Chattopadhyay N, Fonge H, Cai ZL, Scollard D, Lechtman E, Done SJ, Pignol JP, Reilly RM (2012) Role of Antibody-Mediated Tumor Targeting and Route of Administration in Nanoparticle Tumor Accumulation in Vivo. Molecular Pharmaceutics 9:2168-2179

Chen HY, Li SL, Li BW, Ren XY, Li SN, Mahounga DM, Cui SS, Gu YQ, Achilefu S (2012) Folate-modified gold nanoclusters as near-infrared fluorescent probes for tumor imaging and therapy. Nanoscale 4:6050-6064

Chen YS, Hung YC, Liau I, Huang GS (2009) Assessment of the In Vivo Toxicity of Gold Nanoparticles. Nanoscale Res Lett 4:858-864

Cheng MM, Cuda G, Bunimovich YL, Gaspari M, Heath JR, Hill HD, Mirkin CA, Nijdam AJ, Terracciano R, Thundat T, Ferrari M (2006) Nanotechnologies for biomolecular detection and medical diagnostics. Curr Opin Chem Biol 10:11-19

Comenge J, Sotelo C, Romero F, Gallego O, Barnadas A, Parada TGC, Dominguez F, Puntes VF (2012) Detoxifying Antitumoral Drugs via Nanoconjugation: The Case of Gold Nanoparticles and Cisplatin. Plos One 7:

Conde J, Ambrosone A, Sanz V, Hernandez Y, Marchesano V, Tian F, Child H, Berry CC, Ibarra MR, Baptista PV, Tortiglione C, de la Fuente JM (2012a) Design of Multifunctional Gold Nanoparticles for In Vitro and In Vivo Gene Silencing. ACS Nano

Conde J, de la Fuente JM, Baptista PV (2010a) In vitro transcription and translation inhibition via DNA functionalized gold nanoparticles. Nanotechnology 21:505101

Conde J, de la Fuente JM, Baptista PV (2010b) RNA quantification using gold nanoprobes application to cancer diagnostics. J Nanobiotechnology 8:5

Conde J, Doria G, Baptista P (2012b) Noble metal nanoparticles applications in cancer. J Drug Deliv 2012:751075 
Conde J, Doria G, de la Fuente JM, Baptista PV (2012c) RNA quantification using noble metal nanoprobes: simultaneous identification of several different mRNA targets using color multiplexing and application to cancer diagnostics. Methods Mol Biol 906:71-87

Conde J, Larguinho M, Cordeiro A, Raposo LR, Costa PM, Santos S, Diniz MS, Fernandes AR, Baptista PV (2013a) Gold-nanobeacons for gene therapy: evaluation of genotoxicity, cell toxicity and proteome profiling analysis. Nanotoxicology

Conde J, Rosa J, de la Fuente JM, Baptista PV (2013b) Gold-nanobeacons for simultaneous gene specific silencing and intracellular tracking of the silencing events. Biomaterials 34:2516-2523

Conde J, Tian F, Hernandez Y, Bao C, Cui D, Janssen KP, Ibarra MR, Baptista PV, Stoeger T, de la Fuente JM (2013c) In vivo tumor targeting via nanoparticle-mediated therapeutic siRNA coupled to inflammatory response in lung cancer mouse models. Biomaterials 34:7744-7753

Connor EE, Mwamuka J, Gole A, Murphy CJ, Wyatt MD (2005) Gold nanoparticles are taken up by human cells but do not cause acute cytotoxicity. Small 1:325-327

Costa P, Amaro A, Botelho A, Inacio J, Baptista PV (2009) Gold nanoprobes assay for identification of mycobacteria from the Mycobacterium tuberculosis complex. Clin Microbiol Infect

Cuenca AG, Jiang H, Hochwald SN, Delano M, Cance WG, Grobmyer SR (2006) Emerging implications of nanotechnology on cancer diagnostics and therapeutics. Cancer 107:459-466

Daniel MC, Astruc D (2004) Gold nanoparticles: assembly, supramolecular chemistry, quantumsize-related properties, and applications toward biology, catalysis, and nanotechnology. Chem Rev 104:293-346

Dobrovolskaia MA, Aggarwal P, Hall JB, McNeil SE (2008) Preclinical studies to understand nanoparticle interaction with the immune system and its potential effects on nanoparticle biodistribution. Mol Pharm 5:487-495

Dobrovolskaia MA, McNeil SE (2007) Immunological properties of engineered nanomaterials. Nat Nanotechnol 2:469-478

Doria G, Conde J, Veigas B, Giestas L, Almeida C, Assuncao M, Rosa J, Baptista PV (2012) Noble metal nanoparticles for biosensing applications. Sensors (Basel) 12:1657-1687

Doria G, Franco R, Baptista P (2007a) Nanodiagnostics: fast colorimetric method for single nucleotide polymorphism/mutation detection. IET Nanobiotechnol 1:53-57

Doria G, Franco R, Baptista P (2007b) Nanodiagnostics: fast colorimetric method for single nucleotide polymorphism/mutation detection. IET Nanobiotechnol 1:53-57

Dreaden EC, Mwakwari SC, Sodji QH, Oyelere AK, El-Sayed MA (2009) Tamoxifen-Poly(ethylene glycol)-Thiol Gold Nanoparticle Conjugates: Enhanced Potency and Selective Delivery for Breast Cancer Treatment. Bioconjugate Chemistry 20:2247-2253

Eck W, Craig G, Sigdel A, Ritter G, Old LJ, Tang L, Brennan MF, Allen PJ, Mason MD (2008) PEGylated gold nanoparticles conjugated to monoclonal F19 antibodies as targeted labeling agents for human pancreatic carcinoma tissue. ACS Nano 2:2263-2272 
Ehdaie B (2007) Application of nanotechnology in cancer research: review of progress in the National Cancer Institute's Alliance for Nanotechnology. Int J Biol Sci 3:108-110

El-Sayed IH, Huang X, El-Sayed MA (2005a) Surface plasmon resonance scattering and absorption of anti-EGFR antibody conjugated gold nanoparticles in cancer diagnostics: applications in oral cancer. Nano Lett 5:829-834

El-Sayed IH, Huang X, El-Sayed MA (2006) Selective laser photo-thermal therapy of epithelial carcinoma using anti-EGFR antibody conjugated gold nanoparticles. Cancer Lett 239:129-135

El-Sayed ME, Hoffman AS, Stayton PS (2005b) Smart polymeric carriers for enhanced intracellular delivery of therapeutic macromolecules. Expert Opin Biol Ther 5:23-32

Elghanian R, Storhoff JJ, Mucic RC, Letsinger RL, Mirkin CA (1997) Selective colorimetric detection of polynucleotides based on the distance-dependent optical properties of gold nanoparticles. Science 277:1078-1081

Etzioni R, Urban N, Ramsey S, McIntosh M, Schwartz S, Reid B, Radich J, Anderson G, Hartwell L (2003) The case for early detection. Nat Rev Cancer 3:243-252

Ferrari M (2005) Cancer nanotechnology: opportunities and challenges. Nat Rev Cancer 5:161-171

Fichou Y, Ferec C (2006) The potential of oligonucleotides for therapeutic applications. Trends Biotechnol 24:563-570

Fire A, Xu S, Montgomery MK, Kostas SA, Driver SE, Mello CC (1998) Potent and specific genetic interference by double-stranded RNA in Caenorhabditis elegans. Nature 391:806-811

Freese C, Uboldi C, Gibson MI, Unger RE, Weksler BB, Romero IA, Couraud PO, Kirkpatrick CJ (2012) Uptake and cytotoxicity of citrate-coated gold nanospheres: Comparative studies on human endothelial and epithelial cells. Part Fibre Toxicol 9:23

Gary DJ, Puri N, Won YY (2007) Polymer-based siRNA delivery: Perspectives on the fundamental and phenomenological distinctions from polymer-based DNA delivery. Journal of Controlled Release 121:64-73

Ghosh P, Han G, De M, Kim CK, Rotello VM (2008a) Gold nanoparticles in delivery applications. Adv Drug Deliv Rev 60:1307-1315

Ghosh P, Han G, De M, Kim CK, Rotello VM (2008b) Gold nanoparticles in delivery applications. Adv Drug Deliv Rev 60:1307-1315

Ghosh PS, Kim CK, Han G, Forbes NS, Rotello VM (2008c) Efficient gene delivery vectors by tuning the surface charge density of amino acid-functionalized gold nanoparticles. ACS Nano 2:2213-2218

Gibson JD, Khanal BP, Zubarev ER (2007) Paclitaxel-functionalized gold nanoparticles. J Am Chem Soc 129:11653-11661

Gil PR, Parak WJ (2008) Composite nanoparticles take aim at cancer. ACS Nano 2:2200-2205 
Giljohann DA, Seferos DS, Daniel WL, Massich MD, Patel PC, Mirkin CA (2010) Gold

Nanoparticles for Biology and Medicine. Angew Chem Int Ed Engl 49:3280-3294

Giljohann DA, Seferos DS, Prigodich AE, Patel PC, Mirkin CA (2009) Gene regulation with polyvalent siRNA-nanoparticle conjugates. J Am Chem Soc 131:2072-2073

Goodman CM, McCusker CD, Yilmaz T, Rotello VM (2004) Toxicity of gold nanoparticles functionalized with cationic and anionic side chains. Bioconjug Chem 15:897-900

Grubisha DS, Lipert RJ, Park HY, Driskell J, Porter MD (2003) Femtomolar detection of prostatespecific antigen: An immunoassay based on surface-enhanced Raman scattering and immunogold labels. Analytical Chemistry 75:5936-5943

Guo S, Huang Y, Jiang Q, Sun Y, Deng L, Liang Z, Du Q, Xing J, Zhao Y, Wang PC, Dong A, Liang XJ (2010) Enhanced gene delivery and siRNA silencing by gold nanoparticles coated with charge-reversal polyelectrolyte. ACS Nano 4:5505-5511

Hainfeld JF, Dilmanian FA, Slatkin DN, Smilowitz HM (2008) Radiotherapy enhancement with gold nanoparticles. J Pharm Pharmacol 60:977-985

Hainfeld JF, Slatkin DN, Smilowitz HM (2004) The use of gold nanoparticles to enhance radiotherapy in mice. Phys Med Biol 49:N309-N315

Han G, Ghosh P, Rotello VM (2007a) Functionalized gold nanoparticles for drug delivery. Nanomedicine (Lond) 2:113-123

Han G, Ghosh P, Rotello VM (2007b) Multi-functional gold nanoparticles for drug delivery. Adv Exp Med Biol 620:48-56

Hanahan D, Weinberg RA (2000) The hallmarks of cancer. Cell 100:57-70

Hannon GJ, Rossi JJ (2004) Unlocking the potential of the human genome with RNA interference. Nature 431:371-378

Heath JR, Davis ME (2008) Nanotechnology and cancer. Annu Rev Med 59:251-265

Hirsch LR, Stafford RJ, Bankson JA, Sershen SR, Rivera B, Price RE, Hazle JD, Halas NJ, West JL (2003) Nanoshell-mediated near-infrared thermal therapy of tumors under magnetic resonance guidance. Proc Natl Acad Sci U S A 100:13549-13554

Hong R, Han G, Fernandez JM, Kim BJ, Forbes NS, Rotello VM (2006) Glutathione-mediated delivery and release using monolayer protected nanoparticle carriers. J Am Chem Soc 128:10781079

Huang L, Reekmans G, Saerens D, Friedt JM, Frederix F, Francis L, Muyldermans S, Campitelli A, Van HC (2005) Prostate-specific antigen immunosensing based on mixed self-assembled monolayers, camel antibodies and colloidal gold enhanced sandwich assays. Biosens Bioelectron 21:483-490

Huang XL, Zhang B, Ren L, Ye SF, Sun LP, Zhang QQ, Tan MC, Chow GM (2008) In vivo toxic studies and biodistribution of near infrared sensitive $\mathrm{Au}-\mathrm{Au}(2) \mathrm{S}$ nanoparticles as potential drug delivery carriers. J Mater Sci Mater Med 19:2581-2588 
Huo Q, Colon J, Cordero A, Bogdanovic J, Baker CH, Goodison S, Pensky MY (2011) A facile nanoparticle immunoassay for cancer biomarker discovery. J Nanobiotechnology 9:20

Huo Q, Litherland SA, Sullivan S, Hallquist H, Decker DA, Rivera-Ramirez I (2012) Developing a nanoparticle test for prostate cancer scoring. J Transl Med 10:44

Hwu JR, Lin YS, Josephrajan T, Hsu MH, Cheng FY, Yeh CS, Su WC, Shieh DB (2009) Targeted Paclitaxel by conjugation to iron oxide and gold nanoparticles. J Am Chem Soc 131:66-68

Jensen GC, Krause CE, Sotzing GA, Rusling JF (2011) Inkjet-printed gold nanoparticle electrochemical arrays on plastic. Application to immunodetection of a cancer biomarker protein. Physical Chemistry Chemical Physics 13:4888-4894

Kah JC, Kho KW, Lee CG, James C, Sheppard R, Shen ZX, Soo KC, Olivo MC (2007) Early diagnosis of oral cancer based on the surface plasmon resonance of gold nanoparticles. Int $\mathbf{J}$ Nanomedicine 2:785-798

Kalogianni DP, Bravou V, Christopoulos TK, Ioannou PC, Zoumbos NC (2007) Dry-reagent disposable dipstick test for visual screening of seven leukemia-related chromosomal translocations. Nucleic Acids Research 35:

Kang JH, Asami Y, Murata M, Kitazaki H, Sadanaga N, Tokunaga E, Shiotani S, Okada S, Maehara Y, Niidome T, Hashizume M, Mori T, Katayama Y (2010) Gold nanoparticle-based colorimetric assay for cancer diagnosis. Biosens Bioelectron 25:1869-1874

Kim CK, Ghosh P, Pagliuca C, Zhu ZJ, Menichetti S, Rotello VM (2009a) Entrapment of hydrophobic drugs in nanoparticle monolayers with efficient release into cancer cells. J Am Chem Soc 131:1360-1361

Kim D, Jeong YY, Jon S (2010) A Drug-Loaded Aptamer-Gold Nanoparticle Bioconjugate for Combined CT Imaging and Therapy of Prostate Cancer. ACS Nano 4:3689-3696

Kim KY (2007) Nanotechnology platforms and physiological challenges for cancer therapeutics. Nanomedicine 3:103-110

Kim SS, Garg H, Joshi A, Manjunath N (2009b) Strategies for targeted nonviral delivery of siRNAs in vivo. Trends Mol Med 15:491-500

Kneipp J, Kneipp H, McLaughlin M, Brown D, Kneipp K (2006) In vivo molecular probing of cellular compartments with gold nanoparticles and nanoaggregates. Nano Lett 6:2225-2231

Kong KV, Lam Z, Goh WD, Leong WK, Olivo M (2012) Metal Carbonyl-Gold Nanoparticle Conjugates for Live-Cell SERS Imaging. Angewandte Chemie-International Edition 51:9796-9799

Kumar S, Harrison N, Richards-Kortum R, Sokolov K (2007) Plasmonic nanosensors for imaging intracellular biomarkers in live cells. Nano Lett 7:1338-1343

Lammers T, Aime S, Hennink WE, Storm G, Kiessling F (2011) Theranostic nanomedicine. Acc Chem Res 44:1029-1038

Lammers T, Kiessling F, Hennink WE, Storm G (2010) Nanotheranostics and image-guided drug delivery: current concepts and future directions. Mol Pharm 7:1899-1912 
Lan T, Dong C, Huang X, Ren J (2011) Single particle technique for one-step homogeneous detection of cancer marker using gold nanoparticle probes. Analyst 136:4247-4253

Langer R (2000) Biomaterials in drug delivery and tissue engineering: one laboratory's experience. Acc Chem Res 33:94-101

Lasagna-Reeves C, Gonzalez-Romero D, Barria MA, Olmedo I, Clos A, Sadagopa Ramanujam VM, Urayama A, Vergara L, Kogan MJ, Soto C (2010) Bioaccumulation and toxicity of gold nanoparticles after repeated administration in mice. Biochem Biophys Res Commun 393:649-655

Lee JS, Green JJ, Love KT, Sunshine J, Langer R, Anderson DG (2009) Gold, poly(beta-amino ester) nanoparticles for small interfering RNA delivery. Nano Lett 9:2402-2406

Lee SH, Bae KH, Kim SH, Lee KR, Park TG (2008) Amine-functionalized gold nanoparticles as non-cytotoxic and efficient intracellular siRNA delivery carriers. Int J Pharm 364:94-101

Lee SK, Han MS, Asokan S, Tung CH (2011) Effective Gene Silencing by Multilayered siRNACoated Gold Nanoparticles. Small 7:364-370

Li H, Li WX, Ding SW (2002) Induction and suppression of RNA silencing by an animal virus. Science 296:1319-1321

Li H, Rothberg L (2004) Colorimetric detection of DNA sequences based on electrostatic interactions with unmodified gold nanoparticles. Proc Natl Acad Sci U S A 101:14036-14039

Li J, Chu X, Liu Y, Jiang JH, He Z, Zhang Z, Shen G, Yu RQ (2005) A colorimetric method for point mutation detection using high-fidelity DNA ligase. Nucleic Acids Res 33:e168

Lin D, Feng S, Pan J, Chen Y, Lin J, Chen G, Xie S, Zeng H, Chen R (2011) Colorectal cancer detection by gold nanoparticle based surface-enhanced Raman spectroscopy of blood serum and statistical analysis. Opt Express 19:13565-13577

Liu G, Mao X, Phillips JA, Xu H, Tan W, Zeng L (2009) Aptamer-nanoparticle strip biosensor for sensitive detection of cancer cells. Anal Chem 81:10013-10018

Liu X, Dai Q, Austin L, Coutts J, Knowles G, Zou J, Chen H, Huo Q (2008) A one-step homogeneous immunoassay for cancer biomarker detection using gold nanoparticle probes coupled with dynamic light scattering. J Am Chem Soc 130:2780-2782

Liu Y, Miyoshi H, Nakamura M (2007) Nanomedicine for drug delivery and imaging: a promising avenue for cancer therapy and diagnosis using targeted functional nanoparticles. Int $\mathrm{J}$ Cancer $120: 2527-2537$

Lu W, Arumugam SR, Senapati D, Singh AK, Arbneshi T, Khan SA, Yu H, Ray PC (2010a) Multifunctional oval-shaped gold-nanoparticle-based selective detection of breast cancer cells using simple colorimetric and highly sensitive two-photon scattering assay. ACS Nano 4:1739-1749

Lu W, Zhang GD, Zhang R, Flores LG, Huang Q, Gelovani JG, Li C (2010b) Tumor Site-Specific Silencing of NF-kappa B p65 by Targeted Hollow Gold Nanosphere-Mediated Photothermal Transfection. Cancer Research 70:3177-3188 
Lukianova-Hleb EY, Oginsky AO, Samaniego AP, Shenefelt DL, Wagner DS, Hafner JH, FarachCarson MC, Lapotko DO (2011) Tunable plasmonic nanoprobes for theranostics of prostate cancer. Theranostics 1:3-17

Ma X, Zhao Y, Liang XJ (2011) Theranostic nanoparticles engineered for clinic and pharmaceutics. Acc Chem Res 44:1114-1122

McIntosh CM, Esposito EA, III, Boal AK, Simard JM, Martin CT, Rotello VM (2001) Inhibition of DNA transcription using cationic mixed monolayer protected gold clusters. J Am Chem Soc 123:7626-7629

Medley CD, Smith JE, Tang Z, Wu Y, Bamrungsap S, Tan W (2008) Gold nanoparticle-based colorimetric assay for the direct detection of cancerous cells. Anal Chem 80:1067-1072

Milhavet O, Gary DS, Mattson MP (2003) RNA interference in biology and medicine. Pharmacol Rev 55:629-648

Minelli C, Lowe SB, Stevens MM (2010) Engineering nanocomposite materials for cancer therapy. Small 6:2336-2357

Mirkin CA, Letsinger RL, Mucic RC, Storhoff JJ (1996) A DNA-based method for rationally assembling nanoparticles into macroscopic materials. Nature 382:607-609

Mukerjee A, Ranjan AP, Vishwanatha JK (2012) Combinatorial nanoparticles for cancer diagnosis and therapy. Curr Med Chem 19:3714-3721

Mukherjee P, Bhattacharya R, Bone N, Lee YK, Patra CR, Wang S, Lu L, Secreto C, Banerjee PC, Yaszemski MJ, Kay NE, Mukhopadhyay D (2007) Potential therapeutic application of gold nanoparticles in B-chronic lymphocytic leukemia (BCLL): enhancing apoptosis. J Nanobiotechnology 5:4

Munge BS, Coffey AL, Doucette JM, Somba BK, Malhotra R, Patel V, Gutkind JS, Rusling JF (2011) Nanostructured Immunosensor for Attomolar Detection of Cancer Biomarker Interleukin-8 Using Massively Labeled Superparamagnetic Particles. Angewandte Chemie-International Edition 50:7915-7918

Nam JM, Thaxton CS, Mirkin CA (2003) Nanoparticle-based bio-bar codes for the ultrasensitive detection of proteins. Science 301:1884-1886

Nasrolahi SA, Mandal D, Tiwari RK, Guo L, Lu W, Parang K (2012) Cyclic Peptide-Capped Gold Nanoparticles as Drug Delivery Systems. Mol Pharm

Nishiyama N (2007) Nanomedicine: nanocarriers shape up for long life. Nat Nanotechnol 2:203-204

Oishi M, Nakaogami J, Ishii T, Nagasaki Y (2006) Smart PEGylated gold nanoparticles for the cytoplasmic delivery of siRNA to induce enhanced gene silencing. Chemistry Letters 35:1046-1047

Paciotti GF, Myer L, Weinreich D, Goia D, Pavel N, McLaughlin RE, Tamarkin L (2004) Colloidal gold: a novel nanoparticle vector for tumor directed drug delivery. Drug Deliv 11:169-183

Pan Y, Neuss S, Leifert A, Fischler M, Wen F, Simon U, Schmid G, Brandau W, Jahnen-Dechent W (2007) Size-dependent cytotoxicity of gold nanoparticles. Small 3:1941-1949 
Peer D, Karp JM, Hong S, Farokhzad OC, Margalit R, Langer R (2007) Nanocarriers as an emerging platform for cancer therapy. Nat Nanotechnol 2:751-760

Pene F, Courtine E, Cariou A, Mira JP (2009) Toward theragnostics. Crit Care Med 37:S50-S58

Praetorius NP, Mandal TK (2007) Engineered nanoparticles in cancer therapy. Recent Pat Drug Deliv Formul 1:37-51

Qian X, Peng XH, Ansari DO, Yin-Goen Q, Chen GZ, Shin DM, Yang L, Young AN, Wang MD, Nie S (2008a) In vivo tumor targeting and spectroscopic detection with surface-enhanced Raman nanoparticle tags. Nat Biotechnol 26:83-90

Qian X, Zhou X, Nie S (2008b) Surface-enhanced Raman nanoparticle beacons based on bioconjugated gold nanocrystals and long range plasmonic coupling. J Am Chem Soc 130:1493414935

Qin WJ, Yung LY (2007) Nanoparticle-based detection and quantification of DNA with single nucleotide polymorphism (SNP) discrimination selectivity. Nucleic Acids Res 35:e111

Rahman M, Abd-El-Barr M, Mack V, Tkaczyk T, Sokolov K, Richards-Kortum R, Descour M (2005) Optical imaging of cervical pre-cancers with structured illumination: an integrated approach. Gynecol Oncol 99:S112-S115

Rana S, Bajaj A, Mout R, Rotello VM (2012) Monolayer coated gold nanoparticles for delivery applications. Adv Drug Deliv Rev 64:200-216

Rosi NL, Giljohann DA, Thaxton CS, Lytton-Jean AK, Han MS, Mirkin CA (2006) Oligonucleotidemodified gold nanoparticles for intracellular gene regulation. Science 312:1027-1030

Rothen-Rutishauser B, Muhlfeld C, Blank F, Musso C, Gehr P (2007) Translocation of particles and inflammatory responses after exposure to fine particles and nanoparticles in an epithelial airway model. Part Fibre Toxicol 4:9

Salata O (2004) Applications of nanoparticles in biology and medicine. J Nanobiotechnology 2:3

Samanta A, Maiti KK, Soh KS, Liao XJ, Vendrell M, Dinish US, Yun SW, Bhuvaneswari R, Kim H, Rautela S, Chung JH, Olivo M, Chang YT (2011) Ultrasensitive Near-Infrared Raman Reporters for SERS-Based In Vivo Cancer Detection. Angewandte Chemie-International Edition 50:6089-6092

Sato K, Hosokawa K, Maeda M (2003) Rapid aggregation of gold nanoparticles induced by noncross-linking DNA hybridization. J Am Chem Soc 125:8102-8103

Sato K, Hosokawa K, Maeda M (2005) Non-cross-linking gold nanoparticle aggregation as a detection method for single-base substitutions. Nucleic Acids Res 33:e4

Schroeder A, Heller DA, Winslow MM, Dahlman JE, Pratt GW, Langer R, Jacks T, Anderson DG (2012) Treating metastatic cancer with nanotechnology. Nat Rev Cancer 12:39-50

Shi XY, Wang SH, Van Antwerp ME, Chen XS, Baker JR (2009) Targeting and detecting cancer cells using spontaneously formed multifunctional dendrimer-stabilized gold nanoparticles. Analyst 134:1373-1379 
Siegel R, Naishadham D, Jemal A (2012) Cancer statistics, 2012. CA Cancer J Clin 62:10-29

Son SJ, Lee SB (2007) A platform for ultrasensitive and selective multiplexed marker protein assay toward early-stage cancer diagnosis. Nanomedicine (Lond) 2:79-82

Song JB, Zhou JJ, Duan HW (2012) Self-Assembled Plasmonic Vesicles of SERS-Encoded Amphiphilic Gold Nanoparticles for Cancer Cell Targeting and Traceable Intracellular Drug Delivery. Journal of the American Chemical Society 134:13458-13469

Soutschek J, Akinc A, Bramlage B, Charisse K, Constien R, Donoghue M, Elbashir S, Geick A, Hadwiger P, Harborth J, John M, Kesavan V, Lavine G, Pandey RK, Racie T, Rajeev KG, Rohl I, Toudjarska I, Wang G, Wuschko S, Bumcrot D, Koteliansky V, Limmer S, Manoharan M, Vornlocher HP (2004) Therapeutic silencing of an endogenous gene by systemic administration of modified siRNAs. Nature 432:173-178

Sperling RA, Parak WJ (2010) Surface modification, functionalization and bioconjugation of colloidal inorganic nanoparticles. Philos Transact A Math Phys Eng Sci 368:1333-1383

Sperling RA, Rivera GP, Zhang F, Zanella M, Parak WJ (2008) Biological applications of gold nanoparticles. Chem Soc Rev 37:1896-1908

Stiles PL, Dieringer JA, Shah NC, Van Duyne RR (2008) Surface-Enhanced Raman Spectroscopy. Annual Review of Analytical Chemistry 1:601-626

Stoeva SI, Lee JS, Smith JE, Rosen ST, Mirkin CA (2006) Multiplexed detection of protein cancer markers with biobarcoded nanoparticle probes. J Am Chem Soc 128:8378-8379

Storhoff JJ, Lucas AD, Garimella V, Bao YP, Muller UR (2004) Homogeneous detection of unamplified genomic DNA sequences based on colorimetric scatter of gold nanoparticle probes. Nat Biotechnol 22:883-887

Sun X, Rossin R, Turner JL, Becker ML, Joralemon MJ, Welch MJ, Wooley KL (2005) An assessment of the effects of shell cross-linked nanoparticle size, core composition, and surface PEGylation on in vivo biodistribution. Biomacromolecules 6:2541-2554

Taton TA, Mirkin CA, Letsinger RL (2000) Scanometric DNA array detection with nanoparticle probes. Science 289:1757-1760

Thaxton CS, Elghanian R, Thomas AD, Stoeva SI, Lee JS, Smith ND, Schaeffer AJ, Klocker H, Horninger W, Bartsch G, Mirkin CA (2009) Nanoparticle-based bio-barcode assay redefines "undetectable" PSA and biochemical recurrence after radical prostatectomy. Proc Natl Acad Sci U S A 106:18437-18442

Thaxton CS, Georganopoulou DG, Mirkin CA (2006) Gold nanoparticle probes for the detection of nucleic acid targets. Clin Chim Acta 363:120-126

Thomas M, Klibanov AM (2003a) Conjugation to gold nanoparticles enhances polyethylenimine's transfer of plasmid DNA into mammalian cells. Proc Natl Acad Sci U S A 100:9138-9143

Thomas M, Klibanov AM (2003b) Conjugation to gold nanoparticles enhances polyethylenimine's transfer of plasmid DNA into mammalian cells. Proc Natl Acad Sci U S A 100:9138-9143 
Toub N, Malvy C, Fattal E, Couvreur P (2006) Innovative nanotechnologies for the delivery of oligonucleotides and siRNA. Biomed Pharmacother 60:607-620

Uboldi C, Bonacchi D, Lorenzi G, Hermanns MI, Pohl C, Baldi G, Unger RE, Kirkpatrick CJ (2009) Gold nanoparticles induce cytotoxicity in the alveolar type-II cell lines A549 and NCIH441. Part Fibre Toxicol 6:18

Viator JA, Gupta S, Goldschmidt BS, Bhattacharyyal K, Kannan R, Shukla R, Dale PS, Boote E, Katti K (2010) Gold nanoparticle mediated detection of prostate cancer cells using photoacoustic flowmetry with optical reflectance. J Biomed Nanotechnol 6:187-191

Visaria RK, Griffin RJ, Williams BW, Ebbini ES, Paciotti GF, Song CW, Bischof JC (2006) Enhancement of tumor thermal therapy using gold nanoparticle-assisted tumor necrosis factor-alpha delivery. Mol Cancer Ther 5:1014-1020

Wabuyele MB, Yan F, Vo-Dinh T (2010) Plasmonics nanoprobes: detection of single-nucleotide polymorphisms in the breast cancer BRCA1 gene. Analytical and Bioanalytical Chemistry 398:729736

Wall NR, Shi Y (2003) Small RNA: can RNA interference be exploited for therapy? Lancet 362:1401-1403

Wang X, Qian X, Beitler JJ, Chen ZG, Khuri FR, Lewis MM, Shin HJ, Nie S, Shin DM (2011) Detection of circulating tumor cells in human peripheral blood using surface-enhanced Raman scattering nanoparticles. Cancer Res 71:1526-1532

Whitehead KA, Langer R, Anderson DG (2009) Knocking down barriers: advances in siRNA delivery. Nat Rev Drug Discov 8:129-138

Wilson AJ, Willets KA (2013) Surface-enhanced Raman scattering imaging using noble metal nanoparticles. Wiley Interdisciplinary Reviews-Nanomedicine and Nanobiotechnology 5:180-189

Yang J, Eom K, Lim EK, Park J, Kang Y, Yoon DS, Na S, Koh EK, Suh JS, Huh YM, Kwon TY, Haam S (2008) In situ detection of live cancer cells by using bioprobes based on Au nanoparticles. Langmuir 24:12112-12115

Yao L, Danniels J, Moshnikova A, Kuznetsov S, Ahmed A, Engelman DM, Reshetnyak YK, Andreev OA (2013) pHLIP peptide targets nanogold particles to tumors. Proc Natl Acad Sci U S A 110:465-470

Yin ZZ, Liu Y, Jiang LP, Zhu JJ (2011) Electrochemical immunosensor of tumor necrosis factor alpha based on alkaline phosphatase functionalized nanospheres. Biosensors \& Bioelectronics 26:1890-1894

You CC, Miranda OR, Gider B, Ghosh PS, Kim IB, Erdogan B, Krovi SA, Bunz UH, Rotello VM (2007) Detection and identification of proteins using nanoparticle-fluorescent polymer 'chemical nose' sensors. Nat Nanotechnol 2:318-323

You J, Zhang R, Xiong CY, Zhong M, Melancon M, Gupta S, Nick AM, Sood AK, Li C (2012) Effective Photothermal Chemotherapy Using Doxorubicin-Loaded Gold Nanospheres That Target EphB4 Receptors in Tumors. Cancer Research 72:4777-4786 
Zheng D, Giljohann DA, Chen DL, Massich MD, Wang XQ, Iordanov H, Mirkin CA, Paller AS (2012) Topical delivery of siRNA-based spherical nucleic acid nanoparticle conjugates for gene regulation. Proceedings of the National Academy of Sciences of the United States of America 109:11975-11980 


\section{Figure legends}

Figure 1. Nanocarriers for Cancer Theranostics. Nanoparticles-based strategies can be used for biosensing using plasmonic nanosensors for colorimetric assays and bio-bar codes for protein detection or intense labels for immunoassays. Moreover, the use of metal surfaces to enhance the Raman scattering signal of target molecules may be used for cancer diagnostics. Engineered nanocarriers can also act as therapeutic agents via gene silencing and drug delivery systems. Some nanocarriers can be attached to specific targets for selective damage to cancer cells through tumor targeting approaches.

Figure 2. The colorimetric assay. (A) Oligonucleotide probe and target sequences designed for BCR-ABL b3a2 (e14a2) junction and for BCR and ABL genes. Complementary and noncomplementary target sequences were used to study the level of specific interaction between the target and the Au-nanoprobes. BCR-ABL fusion positive (100\% complementary); BCR and ABL gene sequences were used as controls (50\% non-complementary); and a completely unrelated sequence (100\% non-complementary) was used as negative control. (B) The assay is based on the increased stability of the Au-nanoprobes upon hybridization with the complementary target in solution, while non-hybridized Au-nanoprobes easily aggregate once the solution's ionic strength is increased. The absence of full complementarity is revealed by a change of color from red to blue due to A-nanoprobe aggregation which is corroborated by naked eye and UV/vis spectroscopy. BCRABL Positive: sample in the presence of complementary target (solution remains red); BCR-ABL Negative: sample in the presence of non-complementary target (solution turns blue). (C) Spectrophotometry relative to the detection of synthetic BCR-ABL oligonucleotide target. Oligonucleotides with BCR or ABL sequence only (showing 50\% complementarity) were used as controls and an unrelated target (showing 100\% non-complementarity to the Au-nanoprobe) as 
negative control. (D) Detection of BCR-ABL in total RNA from K562 cell line, HL-60 cell line and human PBMC (harboring 50\% complementary targets to the nanoprobe) and S. cerevisiae cells (100\% non-complementary). Nanoprobe aggregation as measured by ratio of area under the curve AUC500 nm-560 nm/AUC570 nm-630 nm. The dashed line represents the threshold of 1 considered for discrimination between Positive and Negative.

\section{Figure 3. Disproportional level between nanoparticle production and their translation into}

clinics. Thousands of systems were published describing different synthesis, biofunctionalization and characterization methods that will most likely revolutionize our understanding of chemical and biological mechanisms and push forward efficient diagnostics and therapeutic platforms.

Nevertheless, very few were produced to improve a bench-to-bedside approach to translational research. Outcomes like this must be followed by extensive laboratory work, which results in improved screening procedures and a new therapy of great potential, although the final product should always be part of a two way interaction between laboratory scientists and clinicians.

Figure 4. Drug delivery. Entrapment of hydrophobic drugs in nanoparticle monolayers with efficient release into cancer cells (A) Delivery of payload to cell through monolayer-membrane interactions. (B) Structure of particles and guest compounds: Bodipy, TAF, and LAP, the number of encapsulated guests per particle, and $\log$ P of the guests. (C) Release of Bodipy from AuNPZwit Bodipy in DCM-aqueous solution two-phase systems ( $\lambda$ ex) $499 \mathrm{~nm}, \lambda \mathrm{em}) 517 \mathrm{~nm}$ ). (D) PL intensity of AuNPZwit-Bodipy in cell culture medium and 100\% serum, indicating little or no release relative to AuNPZwit-Bodipy in PBS after NaCN induced release of guest molecules ( $\lambda$ ex $) 499 \mathrm{~nm}, \lambda \mathrm{em}$ ) $510 \mathrm{~nm}$ ). Reproduced with permission [ Kim et al., 2009a]. Copyright 2013, American Chemical Society. 
Figure 5. NanoToxicity: Causes and Effects. Nanoparticles biocompatibility/effects and their use in biological applications can be influenced by size, shape, solubility, composition and surface charge and modification/chemistry. 
Figures

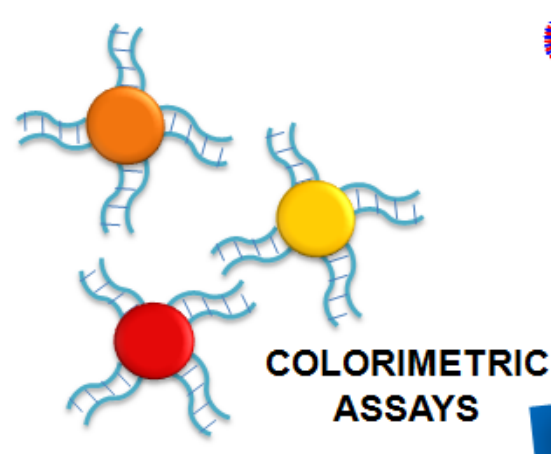

CANCER THERAPY

GENE SILENCING

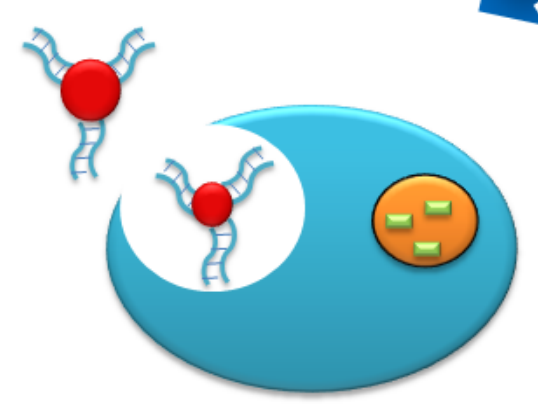

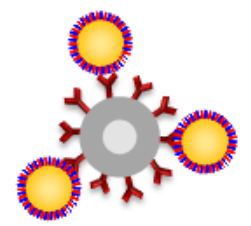

BIO-BAR

CODES
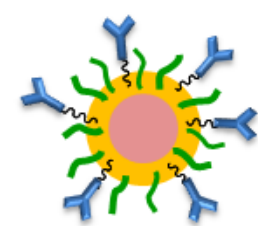

IMMUNOASSAYS
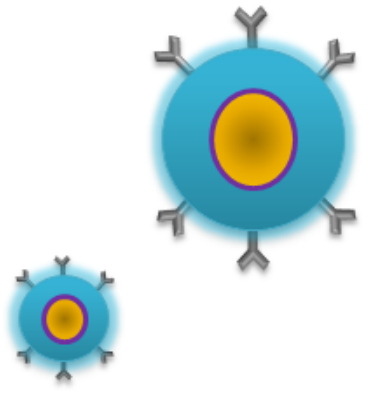

SURFACE ENHANCED

RAMAN SCATTERING

\section{Nanocarriers} for CANCER DIAGNOSTICS

\section{Cancer}

Theragnostics

TUMOR TARGETING
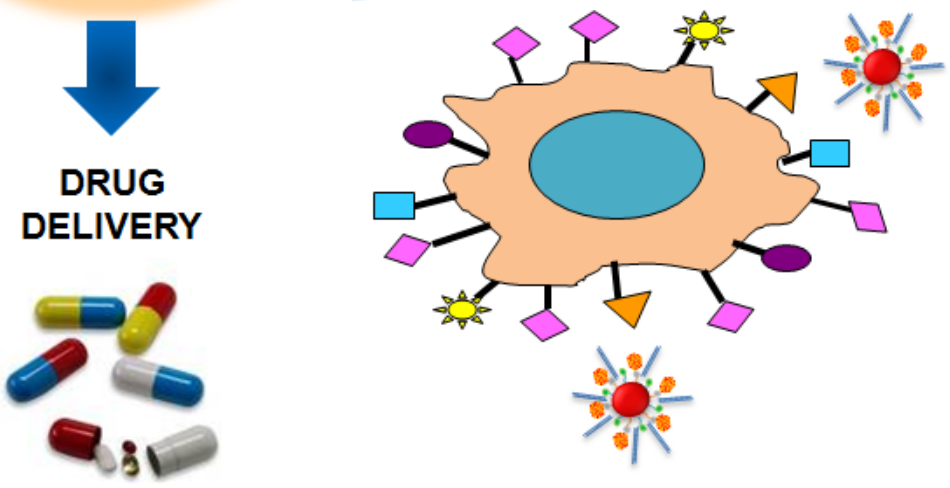

Figure 1 
A

BCRIABL

Fusion region b3a2 (e14a2)

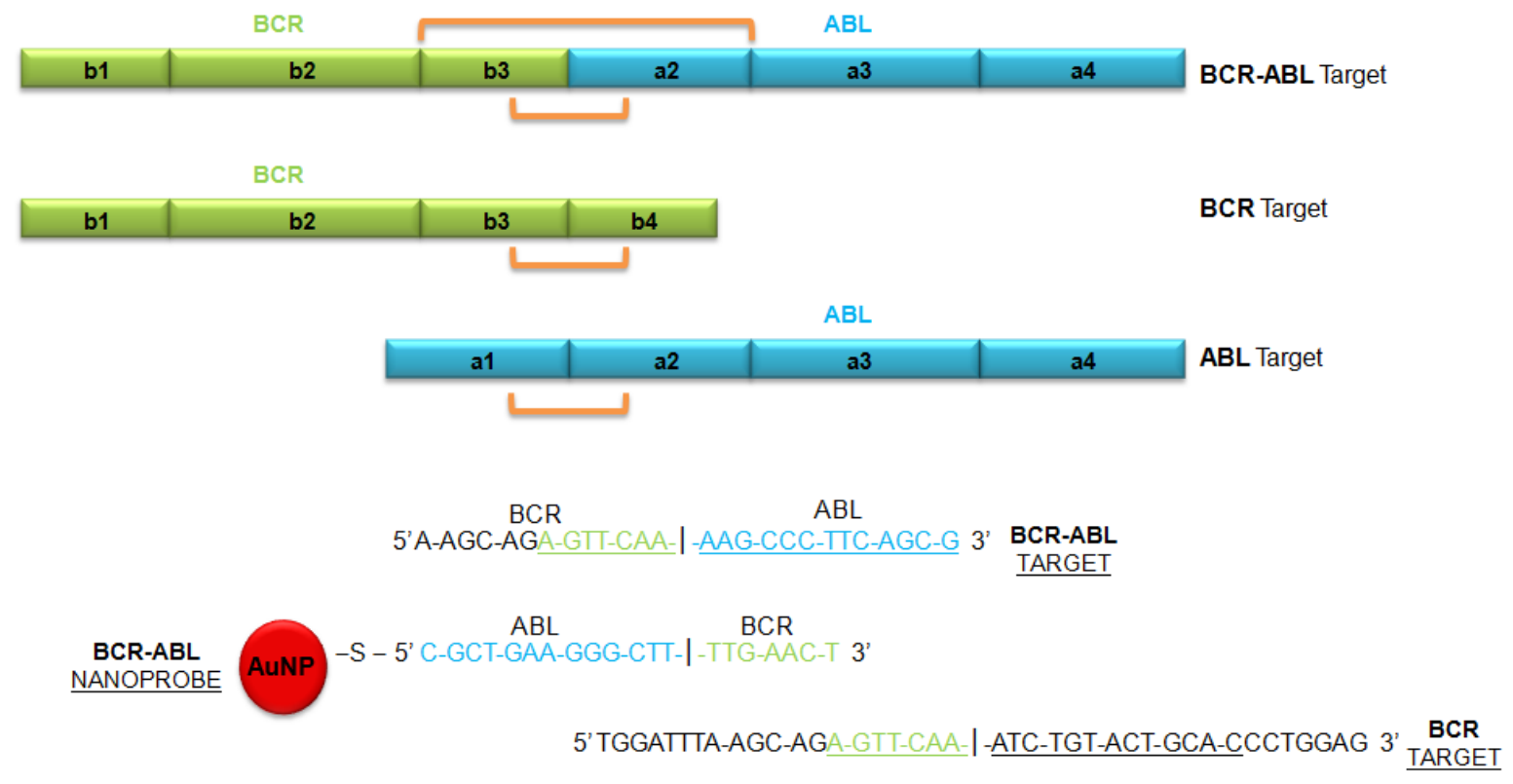

5' CTCCAGCT-GTT-ATC-TGG-AAG -I-AAG-CCC-TTC-AGC-GGCCAGTA 3' ABL

B

BCRLABLb3a2POSITIVE

COMPLEMENTARY TARGET
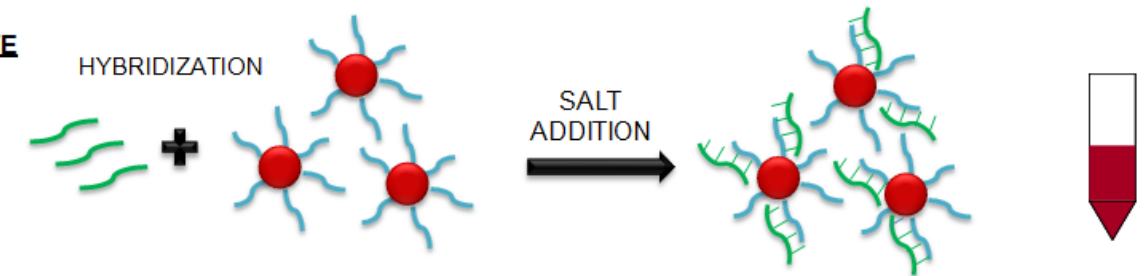

\section{BCRLABLb3a2NEGATIVE}

NON-COMPLEMENTARY TARGET
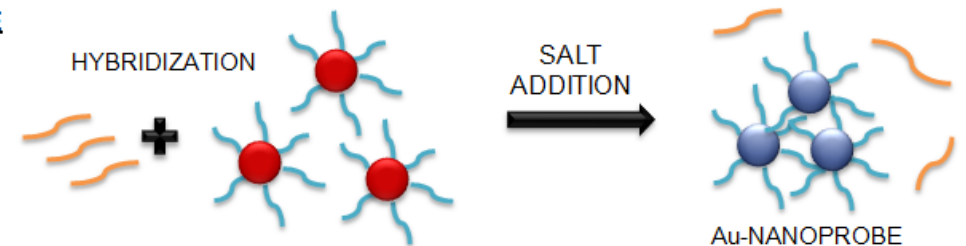

Au-NANOPROBE

C
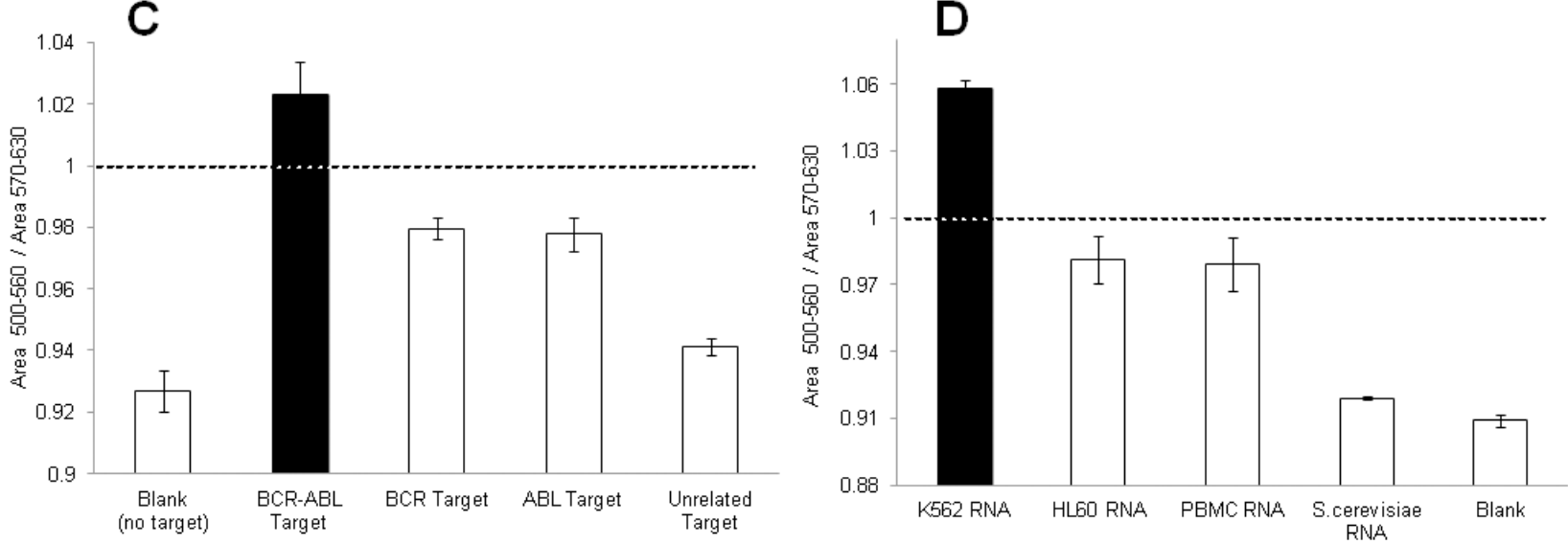

Figure 2 


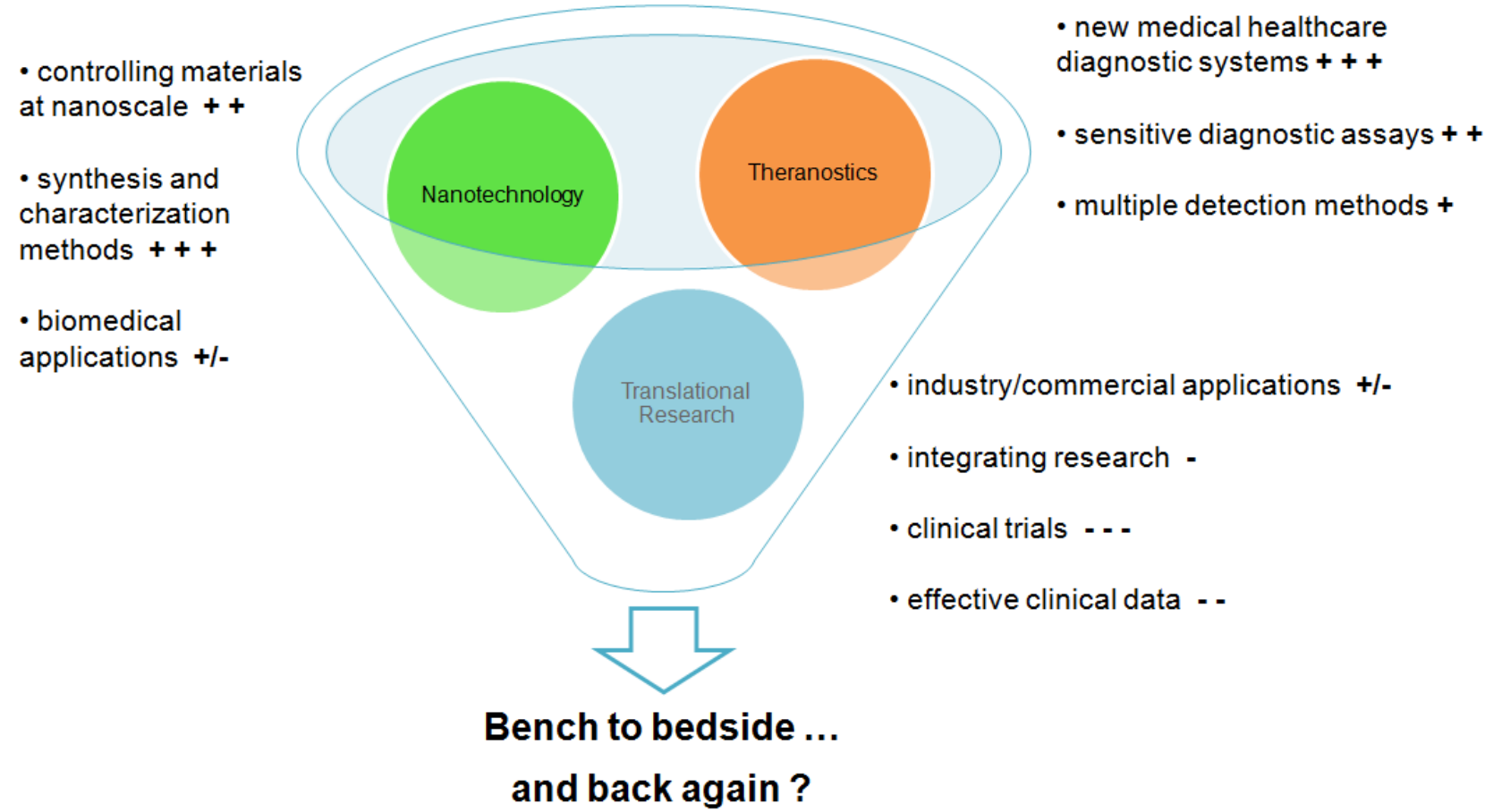

Figure 3 
A

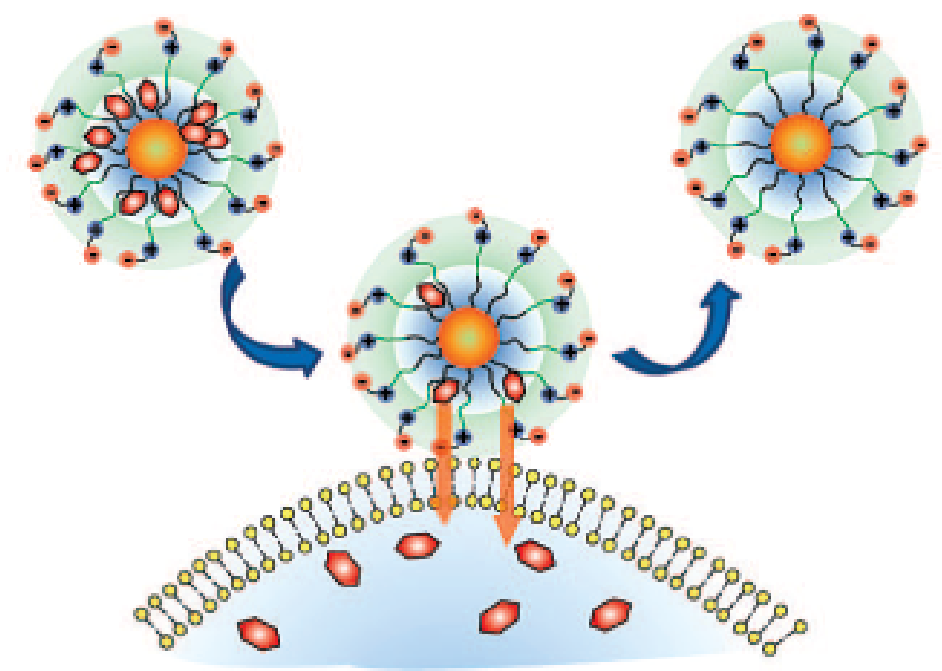

B

Hydrophobic

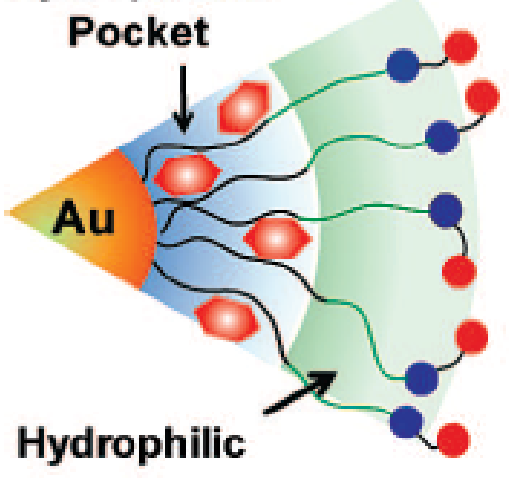

Hydrophilic

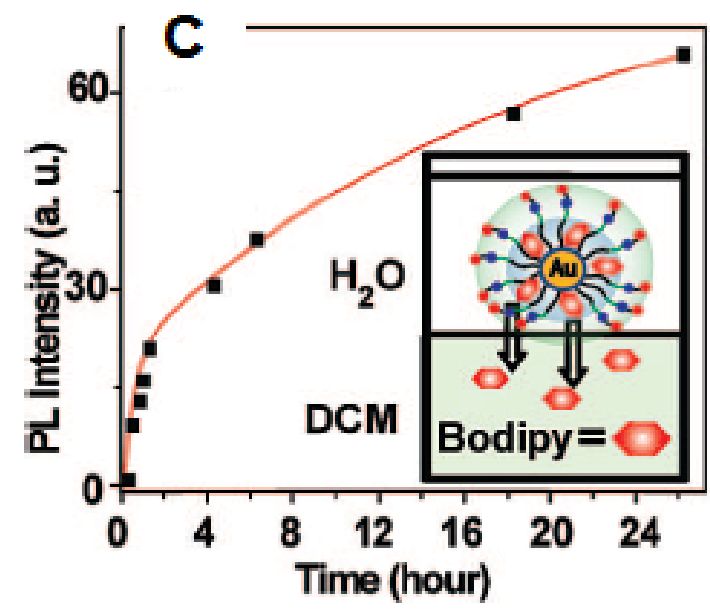

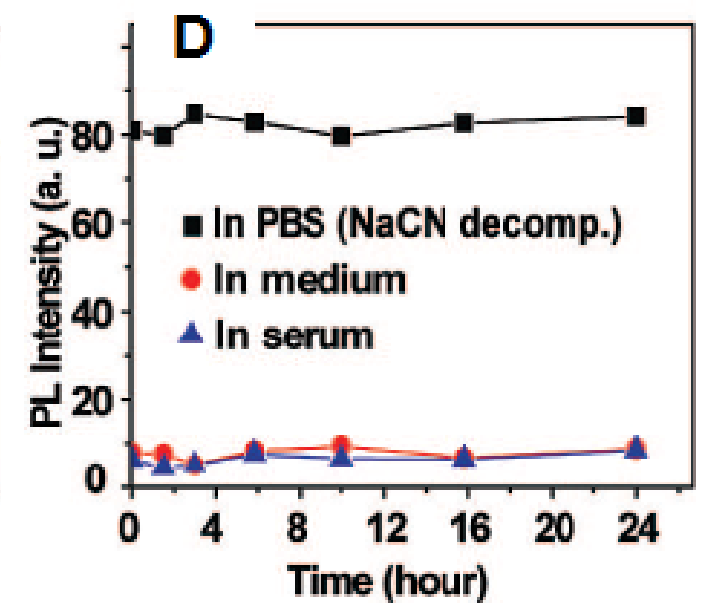

Figure 4 


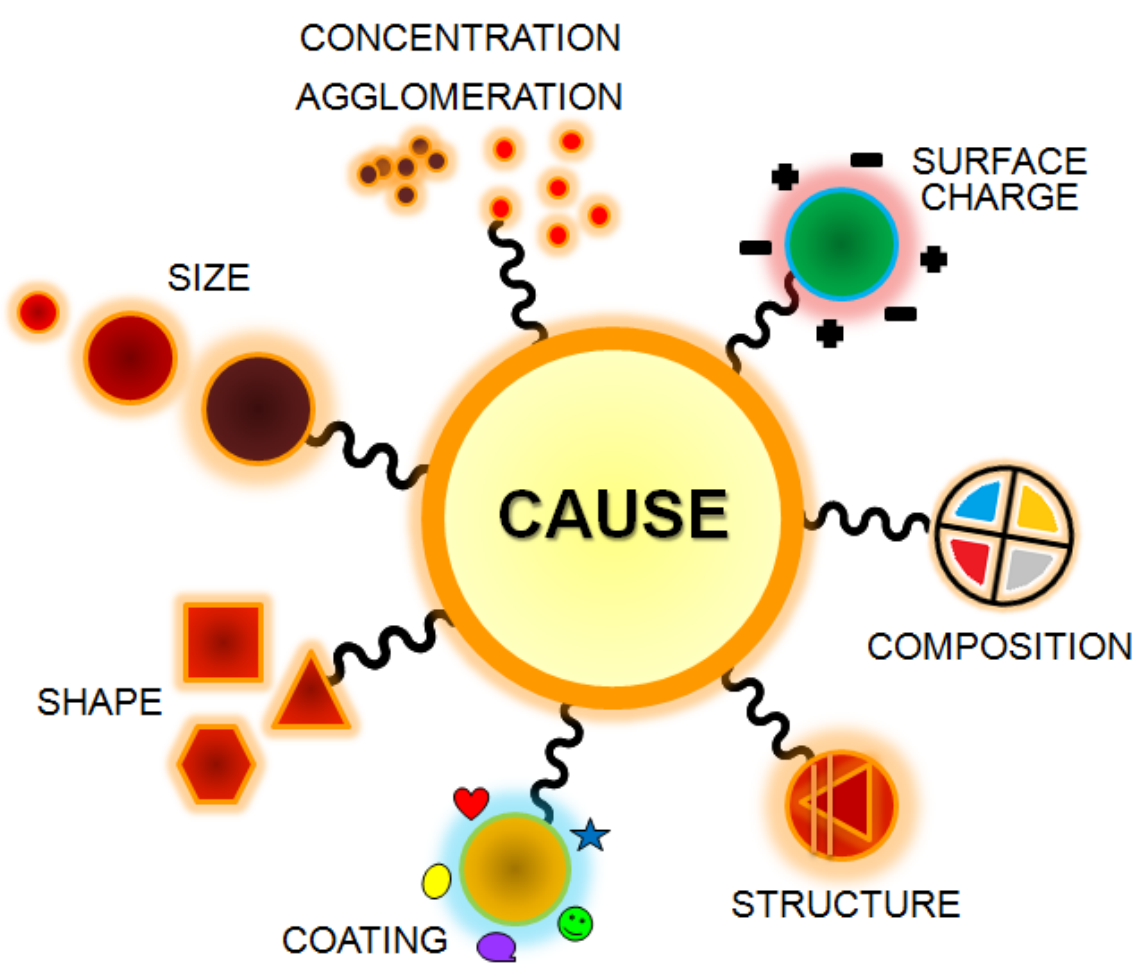

\section{EFFECT}

- Production of ROS

- Membrane damage

- DNA damage

- Mitochondrial damage

- Protein misfolding

- Immunosuppression

- Immunostimulation

- Red blood cells integrity

- Coagulation

- Particle clearance

- Accumulation in organs

Figure 5 